\title{
Application of the Rietveld method to the analysis of anhydrous cement
}

\author{
Gwenn Le Saoût*, Vanessa Kocaba, Karen Scrivener \\ Laboratory of Construction Materials, Swiss Federal Institute of Technology Lausanne (EPFL), Ecublens, CH- 1015 Lausanne, Switzerland
}

\begin{abstract}
A B S T R A C T
X-ray powder diffraction allows direct measurement of the phase content in cement. More recently, whole pattern approaches such as the Rietveld method show an improvement in both within (repeatability) and between laboratory (reproducibility) precision. The aim of this paper is to discuss the influence of the different parameters involved in the Rietveld method and review the most recent quantitative X-ray powder diffraction studies on anhydrous cement. Comparisons with Bogue calculations, scanning electron microscopy and nuclear magnetic resonance are also discussed.
\end{abstract}

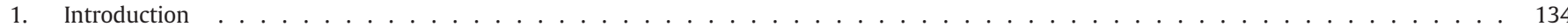

2. Experimental details . . . . . . . . . . . . . . . . . . . . . . . . . . . . . . . . . . . . . . 134

3. The Rietveld analysis . . . . . . . . . . . . . . . . . . . . . . . . . . . . . . . . . . 135

3.1. The Rietveld method . . . . . . . . . . . . . . . . . . . . . . . . . . . . . . . . . . . . . . . . . 135

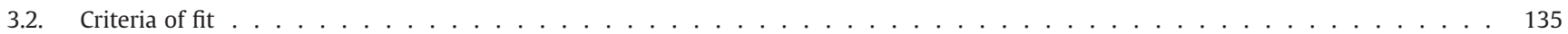

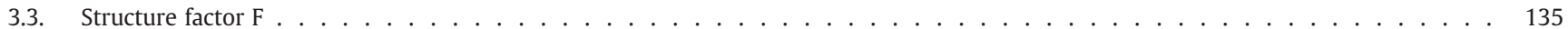

3.3.1. Effect of the choice of alite polymorph on quantification . . . . . . . . . . . . . . . . . . . . . . . . . 136

3.3.2. Effect of the occupancy factor on the simulation and quantification of ferrite . . . . . . . . . . . . . . . . . . . . . 137

3.3.3. Refinement of the occupancy factor for other phases . . . . . . . . . . . . . . . . . . . . . . . . . . . 138

3.4. Absorption contrast . . . . . . . . . . . . . . . . . . . . . . . . . . . . . . . . . . . 139

3.4.1. Results and absorption correction after refinement . . . . . . . . . . . . . . . . . . . . . . . . . . . . . . . 139

3.4.2. Effect of the density on quantification . . . . . . . . . . . . . . . . . . . . . . . . . . 139

3.4.3. Effects of absorption . . . . . . . . . . . . . . . . . . . . . . . . . . . . . . . 139

3.5. Peak shape function $\Phi$. . . . . . . . . . . . . . . . . . . . . . . . . . . . . . . . . 139

3.6. Influence of sample preparation . . . . . . . . . . . . . . . . . . . . . . . . . . . . . . . . . . . . . . . . 140

3.7. Preferred Orientation $(\mathrm{PO})$ function $\mathrm{P}$. . . . . . . . . . . . . . . . . . . . . . . . . . . . . . . . . . . . . 141

3.8. Selective dissolution ... . . . . . . . . . . . . . . . . . . . . . . . . . . . . . . . . . 142

3.9. Precision of the Rietveld method . . . . . . . . . . . . . . . . . . . . . . . . . . . . . . . . . . . . . . . 143

3.9.1. Standard deviation . . . . . . . . . . . . . . . . . . . . . . . . . . . . . . . . . . . 143

4. Guidelines for Rietveld analysis used in the laboratory . . . . . . . . . . . . . . . . . . . . . . . . . . . . . . . . 143

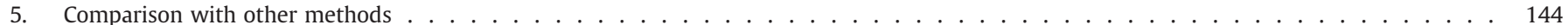

5.1. Bogue and reverse Bogue calculation . . . . . . . . . . . . . . . . . . . . . . . . . . . . . . . . . . . . . . . . 144

5.2. Scanning electron microscopy (SEM) and ${ }^{29}$ Si nuclear magnetic resonance (NMR) . . . . . . . . . . . . . . . . . . . 145

6. Conclusion . . . . . . . . . . . . . . . . . . . . . . . . . . . . . . . . . . . . . 146

Acknowledgements . . . . . . . . . . . . . . . . . . . . . . . . . . . . . . . . . . 146

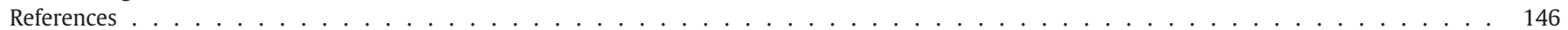

\footnotetext{
* Corresponding author. Present address: Concrete and Construction Chemistry Laboratory, Empa, Swiss Federal Laboratories for Materials Science and Technology, Überlandstrasse 129, CH-8600 Dübendorf, Switzerland. Tel.: +4144823 4417; fax: +41448234035.
}

E-mail address: gwenn.lesaout@empa.ch (G. Le Saoût). 


\section{Introduction}

The quality of the concrete, as assessed by properties such as 28 day strength, is also affected by the relative abundance of the anhydrous phases present in the cement. The most widely used method of estimating the potential phase composition of Portland cement is the Bogue calculation from its oxide analysis [1,2]. However, it is well known that the phase abundance calculated by this method may be far from reality. This is due mainly to the fact that the four main clinker phases are solid solutions with compositions significantly different from the stoichiometric composition of the pure phase [3]. However even for modified Bogue calculations [2], which take the actual composition of the phases into account, small errors in chemical analysis are magnified and lead to large variations in the calculation of phase abundance. As an alternative approach, quantitative X-ray powder diffraction (QXRD) allows a direct measurement of the phase content of cement. More recently, whole pattern approaches, notably with the Rietveld method [4], show an improvement in both within (repeatability) and between laboratory (reproducibility) precision $[5,6]$.

Rietveld phase analysis can be achieved by programming an appropriate refinement strategy including extensive fixing of known parameters in a control file for the anhydrous cement. The input parameters are those given by the crystal structure database but some constraints are added for the unit cell and shape parameters to ensure the stability of the refinement. These constraints are based on a development through extensive calibration with model mixtures and with materials for which the actual phase composition is known by independent methods.

The actual control files used at EPFL are mainly based on the work over several years [7-9] that permit accurate analysis of anhydrous cementitious materials. In parallel, many other groups developed their own control files for quantitative analysis of cement (for examples [10-13]). The innovations in X-ray analysis as the introduction of fast detector combined with the Rietveld analysis lead to the development of QXRD in cement plants for quality control of clinker production [14-20]. However, there are very few papers reviewing QXRD applied on cement using the Rietveld method [21-23].

In this paper, the aim is to review more recent progress on QXRD studies on anhydrous cement and share the experience gained in our laboratory concerning QXRD applied to anhydrous cement carried out in the context of a Nanocem ${ }^{1}$ project on methods to quantify reactions in blended cements. In particular we try to detail the factors limiting the accuracy of Rietveld analysis and the best strategy to obtain the most accurate analyses.

\section{Experimental details}

The chemical composition of the Portland cements studied here, given in Table 1, was determined by X-ray fluorescence (XRF). Their mineralogical composition was calculated by X-ray diffraction/ Rietveld analysis (Table 2) and will be commented on in detail below. Cements $\mathrm{A}$ is a white Portland cement and $\mathrm{F}$ is a sulphate resisting Portland cement, B, C and D are different grey Portland cements, these are all commercial cements. $\mathrm{L}$ is a clinker with a high $\mathrm{SO}_{3}$ content (2.1 wt.\%). To ensure homogeneity for the clinker sample, $150 \mathrm{~g}$ of clinker nodules were ground together to achieve a particle size distribution similar to cement powder.

The instruments settings for the QXRD are described in Table 3. The slit apertures are kept constant during acquisition in order to have a constant irradiated volume with $2 \theta$ angles. All Rietveld refinements

\footnotetext{
${ }^{1}$ www.nanocem.org the research network on cementitious materials.
}

Table 1

Chemical composition of the raw materials and the typical standard deviation of the oxide analyses.

\begin{tabular}{|c|c|c|c|c|c|c|c|}
\hline \multirow[b]{2}{*}{ Oxides (wt.\%) } & \multicolumn{5}{|l|}{ Cement } & \multicolumn{2}{|l|}{ Clinker } \\
\hline & A & $\mathrm{B}$ & $\mathrm{C}$ & $\mathrm{D}$ & $\mathrm{F}$ & $\mathrm{L}$ & SD \\
\hline LOI & 1.0 & 1.9 & 1.3 & 1.3 & 1.0 & 0.3 & 0.10 \\
\hline $\mathrm{Na}_{2} \mathrm{O}$ & 0.17 & 0.24 & 0.20 & 0.26 & 0.25 & 0.38 & 0.03 \\
\hline $\mathrm{MgO}$ & 0.6 & 2.8 & 1.8 & 2.1 & 1.6 & 0.9 & 0.10 \\
\hline $\mathrm{Al}_{2} \mathrm{O}_{3}$ & 2.1 & 5.1 & 4.6 & 5.0 & 4.1 & 5.4 & 0.20 \\
\hline $\mathrm{SiO}_{2}$ & 24.7 & 20.5 & 21.0 & 21.0 & 21.3 & 19.7 & 0.40 \\
\hline $\mathrm{P}_{2} \mathrm{O}_{5}$ & 0.45 & 0.37 & 0.40 & 0.08 & 0.06 & 0.39 & 0.01 \\
\hline $\mathrm{SO}_{3}$ & 1.8 & 2.8 & 2.8 & 3.0 & 2.1 & 2.1 & 0.10 \\
\hline $\mathrm{K}_{2} \mathrm{O}$ & 0.06 & 1.40 & 0.94 & 1.02 & 0.74 & 0.53 & 0.04 \\
\hline $\mathrm{CaO}$ & 68.7 & 61.3 & 64.2 & 63.4 & 63.6 & 66.1 & 0.40 \\
\hline $\mathrm{TiO}_{2}$ & 0.05 & 0.19 & 0.14 & 0.16 & 0.15 & 0.19 & 0.01 \\
\hline $\mathrm{MnO}$ & 0.01 & 0.05 & 0.03 & 0.04 & 0.04 & 0.04 & 0.01 \\
\hline $\mathrm{Fe}_{2} \mathrm{O}_{3}$ & 0.4 & 3.3 & 2.6 & 2.5 & 5.0 & 3.9 & 0.10 \\
\hline $\mathrm{Na}_{2} \mathrm{Oeq}$ & 0.22 & 1.16 & 0.81 & 0.93 & 0.74 & 0.73 & 0.06 \\
\hline Total & 100 & 100 & 100 & 100 & 100 & 100 & \\
\hline
\end{tabular}

were done using the X'Pert High Score Plus program from PANalytical (version 2.1).

The particle size was reduced in a laboratory disc mill from Siebtechnik. By means of predominantly horizontal vibrations, the material is ground by impact and friction, and at the same time homogenized. For wet milling, $4 \mathrm{~g}$ of cement were milled with $15 \mathrm{ml}$

Table 2

Composition of the cement from Rietveld analysis. In parentheses, the standard deviation performed on at least six experiments. The last column SD presents the standard deviation (inter-laboratory experiment) of a round robins $[5,6]$.

\begin{tabular}{|c|c|c|c|c|c|c|c|c|}
\hline Phases (wt.\%) & A & B & C & D & $\mathrm{F}$ & $\mathrm{L}$ & SD [5] & SD [6] \\
\hline Alite $\mathrm{M}_{3}$ & $\begin{array}{l}68.9 \\
(1.7)\end{array}$ & $\begin{array}{l}49.1 \\
(0.8)\end{array}$ & $\begin{array}{l}62.6 \\
(1.8)\end{array}$ & $\begin{array}{l}66.4 \\
(0.4)\end{array}$ & $\begin{array}{l}58.7 \\
(0.7)\end{array}$ & - & 2.3 & 3.2 \\
\hline Alite $\mathrm{M}_{1}$ & - & - & & - & - & $\begin{array}{l}66.3 \\
(1.0)\end{array}$ & & \\
\hline Belite $\beta$ & $\begin{array}{l}23.4 \\
(1.8)\end{array}$ & $\begin{array}{l}18.6 \\
(0.9)\end{array}$ & $\begin{array}{l}16.7 \\
(1.4)\end{array}$ & $\begin{array}{l}14.3 \\
(1.0)\end{array}$ & $\begin{array}{l}17.9 \\
(0.6)\end{array}$ & $\begin{array}{l}14.3 \\
(0.7)\end{array}$ & 1.4 & 2.8 \\
\hline Belite $\alpha_{H}^{\prime}$ & - & $\begin{array}{l}5.6 \\
(0.5)\end{array}$ & - & - & - & - & & \\
\hline Ferrite & - & $\begin{array}{l}11.5 \\
(0.5)\end{array}$ & $\begin{array}{l}7.1 \\
(0.4)\end{array}$ & $\begin{array}{l}9.2 \\
(0.3)\end{array}$ & $\begin{array}{l}16.0 \\
(0.1)\end{array}$ & $\begin{array}{l}14.3 \\
(0.4)\end{array}$ & 1.0 & 1.2 \\
\hline $\begin{array}{l}\text { Aluminate } \\
\text { cubic }\end{array}$ & $\begin{array}{l}3.9 \\
(0.2)\end{array}$ & $\begin{array}{l}3.4 \\
(0.3)\end{array}$ & $\begin{array}{l}5.6 \\
(0.4)\end{array}$ & $\begin{array}{l}3.7 \\
(0.1)\end{array}$ & $\begin{array}{l}0.7 \\
(0.2)\end{array}$ & $\begin{array}{l}5.1 \\
(0.1)\end{array}$ & 0.8 & 1.5 \\
\hline Orthorhombic & - & $\begin{array}{l}2.3 \\
(0.3)\end{array}$ & $\begin{array}{l}1.8 \\
(0.4)\end{array}$ & - & $\begin{array}{l}1.6 \\
(0.3)\end{array}$ & - & & \\
\hline Lime & - & $\begin{array}{l}1.3 \\
(0.4)\end{array}$ & - & - & - & - & 0.4 & \\
\hline Periclase & - & $\begin{array}{l}1.5 \\
(0.2)\end{array}$ & - & $\begin{array}{l}0.4 \\
(0.1)\end{array}$ & $\begin{array}{l}0.5 \\
(0.1)\end{array}$ & - & 0.3 & 0.5 \\
\hline Gypsum & - & - & - & $\begin{array}{l}1.8 \\
(0.3)\end{array}$ & $\begin{array}{l}1.0 \\
(0.3)\end{array}$ & - & 0.6 & 0.5 \\
\hline Hemihydrate & $\begin{array}{l}1.1 \\
(0.1)\end{array}$ & $\begin{array}{l}1.8 \\
(0.1)\end{array}$ & $\begin{array}{l}1.7 \\
(0.1)\end{array}$ & $\begin{array}{l}0.4 \\
(0.2)\end{array}$ & $\begin{array}{l}1.1 \\
(0.3)\end{array}$ & - & 0.8 & 0.7 \\
\hline Anhydrite & $\begin{array}{l}2.1 \\
(0.4)\end{array}$ & $\begin{array}{l}0.9 \\
(0.4)\end{array}$ & $\begin{array}{l}1.0 \\
(0.3)\end{array}$ & $\begin{array}{l}0.6 \\
(0.1)\end{array}$ & - & - & 0.6 & \\
\hline Portlandite & $\begin{array}{l}0.6 \\
(0.2)\end{array}$ & - & - & - & - & - & 0.4 & 0.7 \\
\hline Calcite & - & $\begin{array}{l}1.3 \\
(0.2)\end{array}$ & $\begin{array}{l}0.6 \\
(0.4)\end{array}$ & - & $\begin{array}{l}0.7 \\
(0.2)\end{array}$ & - & 0.5 & 1.9 \\
\hline Dolomite & - & - & $\begin{array}{l}0.3 \\
(0.2)\end{array}$ & - & - & - & - & \\
\hline Arcanite & - & $\begin{array}{l}1.9 \\
(0.2)\end{array}$ & $\begin{array}{l}0.7 \\
(0.3)\end{array}$ & $\begin{array}{l}0.7 \\
(0.2)\end{array}$ & $\begin{array}{l}1.7 \\
(0.2)\end{array}$ & - & 0.4 & \\
\hline Aphthitalite & - & $\begin{array}{l}0.7 \\
(0.2)\end{array}$ & $\begin{array}{l}0.7 \\
(0.1)\end{array}$ & $\begin{array}{l}1.5 \\
(0.1)\end{array}$ & - & - & - & 0.4 \\
\hline Syngenite & - & - & $\begin{array}{l}1.2 \\
(0.4)\end{array}$ & $\begin{array}{l}1.0 \\
(0.4)\end{array}$ & - & - & - & \\
\hline Total & 100 & 100 & 100 & 100 & 100 & 100 & & \\
\hline
\end{tabular}


Table 3

Instrument settings.

\begin{tabular}{|c|c|}
\hline Diffractometer & PANalytical X'Pert Pro MPD \\
\hline Goniometer & $\theta-2 \theta$, radius $240 \mathrm{~mm}$ \\
\hline Source & $\operatorname{CuK}_{\alpha}(\lambda=1.54 \AA)$, line focus \\
\hline Generator & $40 \mathrm{~mA}, 45 \mathrm{kV}$ \\
\hline \multicolumn{2}{|l|}{ Sample } \\
\hline Surface diameter (mm) & 26 \\
\hline Spinning rate (rpm) & 20 \\
\hline Preparation & Backloading \\
\hline \multicolumn{2}{|l|}{ Indicident optics } \\
\hline Monochromator & Focusing Johansson ${ }^{\mathrm{a}}$ \\
\hline Programmable divergence slit & $0.5^{\circ}($ fixed $)$ \\
\hline Incident anti-scatter slit & $1^{\circ}$ \\
\hline \multicolumn{2}{|l|}{ Receiving optics } \\
\hline Programmable anti-scatter slit & $1^{\circ}$ (fixed) \\
\hline Soller slit & 0.04 radians \\
\hline Detector & X'Celerator \\
\hline \multicolumn{2}{|l|}{ Scan info } \\
\hline Angular range $(2 \theta)$ & $5-70^{\circ}$ \\
\hline Step $(2 \theta)$ & 0.017 \\
\hline Length linear detector $(2 \theta)$ & 2.122 \\
\hline Time per step (s) & 100 \\
\hline Measurement time (min) & 51 \\
\hline
\end{tabular}

a The axial divergence of the monochromator is about the same as that of a $0.04 \mathrm{rad}$ Soller slit.

of acetone. The samples were dried in a desiccator to prevent sample contact with atmosphere.

The particle size distribution (PSD) was measured by laser diffraction spectrometer Malvern Mastersizer S using the wet method with isopropyl alcohol as a dispersion medium. Ultrasonic treatment was used to improve the cement dispersion. Each PSD is the mean curve of three measurements. A detailed description of the technique applied to cementitious powders can be found in [24].

The anhydrous cements were prepared for scanning electron microscopy (SEM) examinations in order obtain the actual chemical composition of the different clinker phases used for reverse Bogue calculation. It also gives an independent method (point counting) to quantify the alite to belite ratio. Preparation entailed pressing in pellets; impregnating under vacuum with epoxy resin, careful polishing with decreasing size grades of diamond powders down to $0.25 \mu \mathrm{m}$ and carbon coating to create a conducting layer. These specimens were studied in backscattered electron (BSE) mode using an FEI quanta 200 SEM at an accelerating voltage of $15 \mathrm{kV}$. The chemical composition of each phase of anhydrous cement used in the modified Bogue calculations was established with energy dispersive spectroscopy (EDS) (Table 4). The number of analyses for each phase is also indicated. The electron range is around $2 \mu \mathrm{m}$ at $15 \mathrm{keV}$ [25]. The alite to belite volume ratio was also deduced by SEM point counting method for comparison with XRD results. A large number of analyses are necessary to have a good accuracy. 100 BSE pictures $(0.37 \mu \mathrm{m} /$ pixel) or 400 BSE pictures $(0.185 \mu \mathrm{m} / \mathrm{pixel})$ depending on the particle size were taken. Then a grid of 7000 random points/image was superposed and each point was attributed to the corresponding phase by the operator. Although the SEM examination helps in this study to improve the information available for Rietveld analyses it is very time consuming and not practical on a routine basis, therefore, in the following we try to indicate the likely errors which can be incurred by not taking EDS analyses into account.

\section{The Rietveld analysis}

\subsection{The Rietveld method}

The Rietveld method uses a full profile fitting procedure that overcomes the problem of peak overlap. The intensity at a given $\mathrm{i}^{\text {th }}$ step in the data summing over the p phases in the mixture and where $\mathrm{K}$ stands for plane indices $\mathrm{h}, \mathrm{k}, \mathrm{l}$ is described as [26]:

$\mathrm{y}_{\mathrm{ci}}=\sum_{\mathrm{p}}\left[\mathrm{S}_{\mathrm{p}} \sum_{\mathrm{K}} \mathrm{p}_{\mathrm{K}} \mathrm{L}_{\mathrm{K}}\left|\mathrm{F}_{\mathrm{K}}\right|^{2} \Phi\left(\Delta \theta_{\mathrm{iK}}\right) \mathrm{P}_{\mathrm{K}}\right]+\mathrm{y}_{\mathrm{cbi}}$

where:

$\mathrm{y}_{\mathrm{ci}} \quad$ calculated intensity at the $\mathrm{i}^{\text {th }}$ step in the data,

$\mathrm{S}_{\mathrm{p}} \quad$ scale factor proportional to the number of unit cells contributing to the scattering divided by the unit cell volume, multiplicity factor

$\mathrm{L}_{\mathrm{K}} \quad$ Lorentz and polarisation factors,

$\mathrm{F}_{\mathrm{K}} \quad$ structure factor,

$\Phi$ profile function,

$\mathrm{P}_{\mathrm{K}} \quad$ preferred orientation function,

$\mathrm{y}_{\mathrm{cbi}} \quad$ calculated intensity at the $\mathrm{i}^{\text {th }}$ step of the background.

The quantity minimized in the least-squares refinement is the residual $\sum_{\mathrm{i}} \frac{\left(\mathrm{y}_{\mathrm{i}}-\mathrm{y}_{\mathrm{i}}\right)^{2}}{\mathrm{y}_{\mathrm{i}}}$ summing over all data points and where $\mathrm{y}_{\mathrm{i}}$ is the observed intensity at the $\mathrm{i}^{\text {th }}$ step.

\subsection{Criteria of fit}

Visual examination of a difference profile plot is probably the best way to get a global idea of the fit of the refinement, but it is also possible to calculate numerical agreement indices or $\mathrm{R}$ values (Table 5). As discussed in literature (see [27] and references therein), in order to follow the refinement with a particular dataset, the Rweighted pattern $R_{w p}$ is appropriate, but for comparison of datasets only the structure $R_{B}$ and Bragg $R_{F}$ factors, sensitive to strong and weak Bragg lines respectively, should be used. At the end of the refinement, the correlation matrix also gives indications about the quality of the results. The correlation coefficient $\mathrm{M}_{\mathrm{X}, \mathrm{Y}}$ between two parameters $\mathrm{X}$ and $\mathrm{Y}$ with standard deviations $\sigma_{\mathrm{X}}$ and $\sigma_{\mathrm{Y}}$ is defined as:

$\mathrm{M}_{\mathrm{X}, \mathrm{Y}}=\frac{\operatorname{covariance}(\mathrm{X}, \mathrm{Y})}{\sigma_{\mathrm{X}} \sigma_{\mathrm{Y}}}$

The correlation coefficient indicates the extent to which a change in one parameter will modify the other and so enables one to avoid adjusting separately parameters which are highly correlated (redundant parameters).

\subsection{Structure factor $F$}

The quantitative phase analysis of cements from X-ray powder diffraction data using Rietveld analysis requires the knowledge of the crystal structures of all phases to build the structure factor $\mathrm{F}_{\mathrm{K}}$ :

$F_{K}=\sum_{j} N_{j} f_{j} \exp \left[2 i \pi\left(h x_{j}+k y_{j}+l z_{j}\right)\right] \exp \left(-B_{j}\right)$

where:

$\mathrm{x}_{\mathrm{j}}, \mathrm{y}_{\mathrm{j}}, \mathrm{z}_{\mathrm{j}}$ coordinates of the $\mathrm{j}^{\mathrm{th}}$ atom in the unit cell,

$\mathrm{N}_{\mathrm{j}} \quad$ fractional occupancy for the $\mathrm{j}^{\text {th }}$ atomic site,

$\mathrm{f}_{\mathrm{j}} \quad$ atomic $\mathrm{X}$-ray scattering factor,

$\mathrm{B}_{\mathrm{j}} \quad$ temperature factor.

The atomic positions $\left(\mathrm{x}_{\mathrm{j}}, \mathrm{y}_{\mathrm{j}}, \mathrm{z}_{\mathrm{j}}\right)$, and the isotropic, anisotropic thermal displacement parameters $B_{j}, B_{i j}$ were respectively fixed to their original values. If the thermal displacement parameters are not given, a B value for the isotropic displacement of 0.5 is assumed whereas the anisotropic parameters are fixed to 0 . 
Table 4

Atomic ratios for phases in cement A to F and clinker L calculated from energy dispersive spectroscopy (EDS), *indicated the number of EDS analyses and ** indicated the S content in the belite of clinker L.

\begin{tabular}{|c|c|c|c|c|c|c|c|}
\hline Cement/phases/formulae & $\mathrm{Na}$ & $\mathrm{Ca}$ & $\mathrm{Mg}$ & $\mathrm{Fe}$ & $\mathrm{Al}$ & $\mathrm{Si}$ & 0 \\
\hline \multicolumn{8}{|l|}{ Cement A } \\
\hline Alite $(52)^{*}$ & $<1$ & $292(3)$ & $4(1)$ & $2(1)$ & $7(3)$ & $95(3)$ & 500 \\
\hline $\mathrm{Ca}_{2.92} \mathrm{Mg}_{0.04} \mathrm{Al}_{0.07} \mathrm{Si}_{0.95} \mathrm{O}_{5}$ & 298 & & & & 102 & & \\
\hline Belite (87) & $<1$ & 199(3) & $<1$ & $<1$ & $8(3)$ & $92(3)$ & 400 \\
\hline $\mathrm{Ca}_{1.99} \mathrm{Al}_{0.08} \mathrm{Si}_{0.92} \mathrm{O}_{4}$ & 199 & & & 100 & & & \\
\hline Aluminate (54) & $8(4)$ & $280(10)$ & $3(2)$ & $4(1)$ & $165(18)$ & $30(12)$ & 600 \\
\hline $\mathrm{Ca}_{2.80} \mathrm{Mg}_{0.03} \mathrm{Na}_{0.08} \mathrm{Al}_{1.65} \mathrm{Fe}_{0.04} \mathrm{Si}_{0.30} \mathrm{O}_{6}$ & 291 & & & 199 & & & \\
\hline \multicolumn{8}{|l|}{ Cement B } \\
\hline Alite (87) & $<1$ & $284(5)$ & $8(2)$ & $4(2)$ & $9(5)$ & $93(4)$ & 500 \\
\hline $\mathrm{Ca}_{2.84} \mathrm{Mg}_{0.08} \mathrm{Al}_{0.09} \mathrm{Fe}_{0.04} \mathrm{Si}_{0.93} \mathrm{O}_{5}$ & 297 & & & & 102 & & \\
\hline Belite (78) & $<1$ & $198(3)$ & $2(1)$ & $3(1)$ & $7(3)$ & $92(3)$ & 400 \\
\hline $\mathrm{Ca}_{1.98} \mathrm{Al}_{0.07} \mathrm{Fe}_{0.03} \mathrm{Si}_{0.92} \mathrm{O}_{4}$ & 200 & & & 102 & & & \\
\hline Aluminate (39) & $5(2)$ & $273(5)$ & $5(1)$ & $15(3)$ & $168(10)$ & $22(8)$ & 600 \\
\hline $\mathrm{Ca}_{2.73} \mathrm{Mg}_{0.05} \mathrm{Na}_{0.05} \mathrm{Al}_{1.68} \mathrm{Fe}_{0.15} \mathrm{Si}_{0.22} \mathrm{O}_{6}$ & 283 & & & 205 & & & \\
\hline Ferrite (50) & $<1$ & $194(5)$ & $15(3)$ & $76(13)$ & $100(15)$ & $14(5)$ & 500 \\
\hline \multirow{2}{*}{\multicolumn{8}{|c|}{ Cement C }} \\
\hline & & & & & & & \\
\hline Alite (75) & $<1$ & $294(3)$ & $5(1)$ & $4(2)$ & $5(2)$ & $93(2)$ & 500 \\
\hline $\mathrm{Ca}_{2.94} \mathrm{Mg}_{0.05} \mathrm{Al}_{0.05} \mathrm{Fe}_{0.04} \mathrm{Si}_{0.93} \mathrm{O}_{5}$ & 303 & & & & 99 & & \\
\hline Belite (74) & $<1$ & $200(5)$ & $<1$ & $3(2)$ & $5(3)$ & $91(4)$ & 400 \\
\hline $\mathrm{Ca}_{2.00} \mathrm{Al}_{0.05} \mathrm{Si}_{0.91} \mathrm{O}_{4}$ & 202 & & & 99 & & & \\
\hline Aluminate $(88)$ & $5(2)$ & $277(9)$ & $11(12)$ & $14(4)$ & $162(9)$ & $22(4)$ & 600 \\
\hline $\mathrm{Ca}_{2.77} \mathrm{Na}_{0.05} \mathrm{Al}_{1.62} \mathrm{Fe}_{0.14} \mathrm{Si}_{0.22} \mathrm{O}_{6}$ & 294 & & & 198 & & & \\
\hline Ferrite (78) & $<1$ & $206(3)$ & $18(3)$ & $57(5)$ & $104(8)$ & $17(6)$ & 500 \\
\hline $\mathrm{Ca}_{2.06} \mathrm{Mg}_{0.18} \mathrm{Al}_{1.04} \mathrm{Fe}_{0.57} \mathrm{Si}_{0.17} \mathrm{O}_{5}$ & 206 & & 196 & & & & \\
\hline \multicolumn{8}{|l|}{ Cement D } \\
\hline Alite (82) & $<1$ & $289(3)$ & $8(2)$ & $3(1)$ & $8(2)$ & $93(2)$ & 500 \\
\hline $\mathrm{Ca}_{2.89} \mathrm{Mg}_{0.08} \mathrm{Al}_{0.08} \mathrm{Fe}_{0.03} \mathrm{Si}_{0.93} \mathrm{O}_{5}$ & 300 & & & & 102 & & \\
\hline Belite (70) & $<1$ & $198(2)$ & $2(1)$ & $2(1)$ & $7(1)$ & $91(2)$ & 400 \\
\hline $\mathrm{Ca}_{1.98} \mathrm{Al}_{0.07} \mathrm{Fe}_{0.02} \mathrm{Si}_{0.91} \mathrm{O}_{4}$ & 200 & & & 100 & & & \\
\hline Aluminate (47) & $3(2)$ & $268(15)$ & $23(22)$ & $19(5)$ & 148(19) & $28(11)$ & 600 \\
\hline $\mathrm{Ca}_{2.68} \mathrm{Al}_{1.48} \mathrm{Fe}_{0.19} \mathrm{Si}_{0.28} \mathrm{O}_{6}$ & 294 & & & 195 & & & \\
\hline Ferrite (110) & $<1$ & $209(5)$ & $19(5)$ & $46(6)$ & $109(11)$ & $20(9)$ & 500 \\
\hline $\mathrm{Ca}_{2.09} \mathrm{Mg}_{0.19} \mathrm{Al}_{1.09} \mathrm{Fe}_{0.46} \mathrm{Si}_{0.20} \mathrm{O}_{5}$ & 209 & & 184 & & & & \\
\hline \multicolumn{8}{|l|}{ Cement F } \\
\hline Alite (163) & $<1$ & $288(2)$ & $6(1)$ & $3(1)$ & $6(1)$ & $96(2)$ & 500 \\
\hline $\mathrm{Ca}_{2.97} \mathrm{Mg}_{0.06} \mathrm{Al}_{0.06} \mathrm{Fe}_{0.03} \mathrm{Si}_{0.96} \mathrm{O}_{5}$ & 297 & & & & 102 & & \\
\hline Belite (83) & $<1$ & $197(2)$ & $<1$ & $3(1)$ & $6(1)$ & $93(2)$ & 400 \\
\hline $\mathrm{Ca}_{1.97} \mathrm{Al}_{0.06} \mathrm{Fe}_{0.03} \mathrm{Si}_{0.93} \mathrm{O}_{4}$ & 198 & & & 103 & & & \\
\hline Aluminate & Crystalli & t sufficient & ysis & & & & \\
\hline Ferrite (123) & $<1$ & $210(2)$ & $16(3)$ & $75(6)$ & $89(8)$ & $14(5)$ & 500 \\
\hline $\mathrm{Ca}_{2.10} \mathrm{Mg}_{0.16} \mathrm{Al}_{0.89} \mathrm{Fe}_{0.75} \mathrm{Si}_{0.14} \mathrm{O}_{5}$ & 210 & & 194 & & & & \\
\hline \multicolumn{8}{|l|}{ Clinker L } \\
\hline Alite (130) & $<1$ & $304(2)$ & $4(1)$ & $2(1)$ & $8(1)$ & $88(2)$ & 500 \\
\hline $\mathrm{Ca}_{3.04} \mathrm{Mg}_{0.04} \mathrm{Al}_{0.08} \mathrm{Si}_{0.88} \mathrm{O}_{5}$ & 310 & & & & 96 & & \\
\hline Belite (128) & $<1$ & $204(1)$ & $<1$ & $3(1)$ & $8(1)$ & $83(2)$ & 400 \\
\hline $\mathrm{Ca}_{2.04} \mathrm{Al}_{0.08} \mathrm{Fe}_{0.03} \mathrm{~S}_{0.04} \mathrm{Si}_{0.83} \mathrm{O}_{4}$ & 204 & \multicolumn{6}{|c|}{ 98( $\left(\right.$ content: $\left.4(1)^{* *}\right)$} \\
\hline Aluminate (119) & $<1$ & $299(4)$ & $5(2)$ & $17(4)$ & $154(8)$ & $18(5)$ & 600 \\
\hline $\mathrm{Ca}_{2.99} \mathrm{Mg}_{0.05} \mathrm{Al}_{1.54} \mathrm{Fe}_{0.17} \mathrm{Si}_{0.18} \mathrm{O}_{6}$ & 304 & & & 189 & & & \\
\hline Ferrite (97) & $<1$ & $211(3)$ & $13(2)$ & $78(6)$ & $93(7)$ & $10(4)$ & 500 \\
\hline $\mathrm{Ca}_{2.11} \mathrm{Mg}_{0.13} \mathrm{Al}_{093} \mathrm{Fe}_{0.78} \mathrm{Si}_{0.10} \mathrm{O}_{5}$ & 211 & & 194 & & & & \\
\hline
\end{tabular}

The polymorphism and solid solution of the main cement phases has been previously described (see for examples [28-32] and references therein). The phases used for Rietveld refinement in this

Table 5

Some numerical criteria of fit used in the Rietveld method. $\mathrm{I}_{\mathrm{K}}$ is the observed intensity assigned to the $\mathrm{K}^{\text {th }}$ Brag reflection and $\mathrm{I}_{\mathrm{CK}}$ the calculated intensity [26].

\begin{tabular}{lc}
\hline Agreement indices & $\mathrm{R}_{\mathrm{wp}}=\left[\frac{\left.\sum_{\mathrm{i}} \frac{\left(\mathrm{y}_{\mathrm{i}}-\mathrm{y}_{\mathrm{c}}\right)^{2}}{\sum_{\mathrm{i}} \mathrm{y}_{\mathrm{i}}}\right]^{1 / 2}}{\mathrm{R} \text {-weighted pattern }}\right.$ \\
R-Bragg factor & $\mathrm{R}_{\mathrm{B}}=\frac{\sum_{\mathrm{K}}\left|\mathrm{I}_{\mathrm{K}}-\mathrm{I}_{\mathrm{CK}}\right|}{\sum_{\mathrm{K}} \mathrm{I}_{\mathrm{K}}}$ \\
R-structure factor & $\mathrm{R}_{\mathrm{F}}=\frac{\sum_{\mathrm{K}}\left|\sqrt{\mathrm{I}_{\mathrm{K}}}-\sqrt{\mathrm{I}_{\mathrm{CK}}}\right|}{\sum_{\mathrm{K}} \sqrt{\mathrm{I}_{\mathrm{K}}}}$ \\
\hline
\end{tabular}

study and the ICSD codes (Inorganic Crystal Structure Database, web version 1.1.0) of the structural data are given in Table 6. Some powder diffraction file (PDF) codes (International Centre for Diffraction Data (ICDD) PDF, release 2002) are also presented for information. However, even though the structure of belite, aluminate and ferrite phases are well known, the structure of the different $C_{3} S$ polymorphs is complicated by the orientation disorder of the silicate tetrahedral (Table 7). The polymorphs appear in several cases to be superstructures in which the true unit cell is extremely large but can be approximated by simpler pseudo structure in order to reduce the number of parameters.

\subsubsection{Effect of the choice of alite polymorph on quantification}

In order to select the best alite polymorph, a detailed analysis of selected angular windows $\left(24.5^{\circ}-28.5^{\circ}, 31.5-33.5^{\circ}, 36^{\circ}-38^{\circ}\right.$ and $51^{\circ}-$ $53^{\circ} 2 \theta \mathrm{CuK}_{\alpha}$ ) of each diffractogram was made as proposed by Courtial et al. [60] for the different monoclinic forms. As depicted in Fig. 1, based on the peak shape, the $M_{3}$ polymorph is observed in cement $A$, 
Table 6

References of the different phase structure used for Rietveld analysis.

\begin{tabular}{|c|c|c|c|c|c|c|}
\hline Phases & Formulae & Crystal system notation & ICSD codes & Year & Reference & PDF codes \\
\hline \multirow[t]{2}{*}{ Alite } & \multirow[t]{2}{*}{$\mathrm{C}_{3} \mathrm{SiO}_{5}$} & Monoclinic/ $\mathrm{M}_{3}$ & 94742 & 2002 & de La Torre et al. [33] & 01-070-8632 \\
\hline & & Monoclinic/ $\mathrm{M}_{1}$ & - & 2006 & de Noirfontaine et al. [32] & - \\
\hline \multirow[t]{2}{*}{ Belite } & \multirow[t]{2}{*}{$\mathrm{C}_{2} \mathrm{SiO}_{4}$} & Monoclinic/ $\beta$ & 79550 & 1994 & Tsurumi et al. [34] & 01-083-0460 \\
\hline & & Orthorhombic $/ \alpha_{H}^{\prime}$ & 81097 & 1995 & Mumme et al. [35] & 01-086-0399 \\
\hline \multirow{2}{*}{ Aluminate } & $\mathrm{Ca}_{3} \mathrm{Al}_{2} \mathrm{O}_{6}$ & Cubic & 1841 & 1975 & Mondal et al. [36] & $00-038-1429$ \\
\hline & $\mathrm{Ca}_{8.5} \mathrm{NaAl}_{6} \mathrm{O}_{18}$ & Orthorhombic & 1880 & 1975 & Nishi et al. [37] & $00-032-0150$ \\
\hline Ferrite & $\mathrm{C}_{2} \mathrm{AlFeO}_{5}$ & Orthorhombic & 9197 & 1971 & Colville et al. [38] & 01-071-0667 \\
\hline Lime & $\mathrm{CaO}$ & Cubic & 75785 & 1994 & Huang et al. [39] & $43-1001$ \\
\hline Portlandite & $\mathrm{Ca}(\mathrm{OH})_{2}$ & Rhombohedral & 15471 & 1961 & Petch $[40]$ & 01-072-0156 \\
\hline Periclase & $\mathrm{MgO}$ & Cubic & 104844 & 1984 & Taylor [41] & $45-946$ \\
\hline Calcite & $\mathrm{CaCO}_{3}$ & Rhombohedral & 79673 & 1989 & Wartchow [42] & 01-083-0577 \\
\hline Dolomite & Ca $\mathrm{Mg}\left(\mathrm{CO}_{3}\right)_{2}$ & Trigonal & 31335 & 1983 & Effenberg et al. [43] & $01-075-1761$ \\
\hline Quartz & $\alpha-\mathrm{SiO}_{2}$ & Rhombohedral & 200721 & 1978 & Jorgensen [44] & $01-083-2465$ \\
\hline Gypsum & $\mathrm{CaSO}_{4} \cdot 2 \mathrm{H}_{2} \mathrm{O}$ & Monoclinic & 151692 & 2004 & de La Torre et al. [45] & 33-0311 \\
\hline Hemihydrate & $\mathrm{CaSO}_{4} \cdot 0.5 \mathrm{H}_{2} \mathrm{O}$ & Monoclinic & 380286 & 2009 & Weiss et al. [46] & $41-224$ \\
\hline Anhydrite & $\mathrm{CaSO}_{4}$ & Orthorhombic & 40043 & 1975 & Hawthorne et al. [47] & $01-086-2270$ \\
\hline Arcanite & $\mathrm{K}_{2} \mathrm{SO}_{4}$ & Orthorhombic & 2827 & 1972 & McGinnety [48] & 01-070-1488 \\
\hline Aphthitalite & $\mathrm{K}_{3} \mathrm{Na}\left(\mathrm{SO}_{4}\right)_{2}$ & Trigonal & 26018 & 1980 & Okada et al. [49] & 01-074-0398 \\
\hline Syngenite & $\mathrm{K}_{2} \mathrm{Ca}\left(\mathrm{SO}_{4}\right)_{2}\left(\mathrm{H}_{2} \mathrm{O}\right)$ & Monoclinic & 157072 & 2005 & Ballirano et al. [50] & 00-28-0739 \\
\hline
\end{tabular}

$B, D$, and $F$ (not shown), $M_{1}$ in clinker $L$ whereas $C$ is a mix of $M_{1}$ and $M_{3}$. The occurrence of $M_{1}$ in the clinker $L$ is well supported by the findings of Maki et al. [61] for the dependence of polymorph on the amounts of $\mathrm{MgO}$ and $\mathrm{SO}_{3}$ in clinker. Unfortunately, such correlation is not possible for other samples as the amount of $\mathrm{SO}_{3}$ added on grinding, and therefore clinker $\mathrm{SO}_{3}$ is unknown. The influence of the polymorph on the quantification was investigated for all samples. As depicted in Table 8, the quantification is not much influenced by whether the $M_{1}$ or $M_{3}$ model is used although the criteria of fit $R_{B}$ and $\mathrm{R}_{\mathrm{F}}$ are generally better when the right model is used. For the cement $C$, $\mathrm{M}_{1}$ and $\mathrm{M}_{3}$ models were used together but as these models are close, the correlation matrix reveals significant correlation between scale factors of these two models ( $>0.9$ ). Then if there is a good accuracy of the sum $\mathrm{M}_{1}+\mathrm{M}_{3}$ and a better visual fit as the number of refined parameters increases, the quantitative distribution of $M_{1}$ and $M_{3}$ is doubtful. Therefore, it is probably best to use only one model in the refinement to avoid the use of redundant parameters. Recently, the difference between $\mathrm{M}_{3}$ and $\mathrm{T}_{3}$ forms has been reported by de la Torre et al.[57] in the $29.0^{\circ}-30.5^{\circ}(2 \theta, \mathrm{CuK} \alpha)$ window range but is not observed in our cements even using strictly monochromatic X-rays in order to remove $\mathrm{CuK} \alpha_{2}$ radiation. Furthermore, as clearly show in [57], the quantitative analysis results are not strongly affected by the choice of the polymorph $\mathrm{M}_{3}$ or $\mathrm{T}_{3}$. Although the choice of the polymorph $\mathrm{M}_{1}$ or $\mathrm{M}_{3}$ did not have a strong influence on the quantification for our samples, de Noirfontaine et al. [32] found larger discrepancies for the amount of alite calculated according to the polymorph used: $43.0 \%$ for $\mathrm{M}_{3}$ [55] and $46.1 \%$ for $\mathrm{M}_{1}$ [32] models in a
$M_{3}$ based clinker and $49 \%$ for $M_{3}$ and $53.2 \%$ for $M_{1}$ in a $M_{1}$ based clinker.

\subsubsection{Effect of the occupancy factor on the simulation and quantification of ferrite}

To take into account the solid solution of the ferrite phase where variable occupancy of aluminium and iron on tetrahedral and octahedral sites occurs, the fractional occupancy $\mathrm{N}_{\mathrm{j}}$ of $\mathrm{Al}$ and $\mathrm{Fe}$ in octahedral and tetrahedral positions may be refined [62]. The $\left(\begin{array}{lll}0 & 2 & 0\end{array}\right)$ reflection at $12.1^{\circ} 2 \theta \mathrm{CuK}_{\alpha}$ depends strongly on the distribution of $\mathrm{Al}$ and $\mathrm{Fe}$ in contrast to the main reflection $(141)$ at $33.7^{\circ}$ [63]. In order to illustrate the effect of occupancy on the X-ray pattern, a nitric acid extraction was made (see [64] for procedure) for selective dissolution of the silicate phases leaving the ferrite and sulphate phases. Fig. 2 shows the results of extraction for cement $\mathrm{F}$ that contains the highest amount of ferrite. Refinement of the occupancy factor gives a better simulation of the $\left(\begin{array}{lll}0 & 2 & 0\end{array}\right)$ reflection although the simulation is not perfect due to the asymmetry of this peak (see Section 3.3). Fig. 3 compares the $\mathrm{Al}$ to $\mathrm{Fe}$ atomic ratios deduced from QXRD and EDS analysis (Table 4). The comparison of Al to Fe ratio from the Rietveld refinement with that obtained from EDS data is not so straightforward as EDS analyses detect other minor elements $\mathrm{Si}$, Ti, Mg, etc which may substitute for $\mathrm{Al}$ and $\mathrm{Fe}$ and are not taken into account in the refinement. These substituting elements have different atomic X-ray scattering factors contributing to the structure factor $F_{K}$ (Eq. 3). However, the atomic numbers and hence X-ray scattering factors $f_{j}$ of $\mathrm{Al}, \mathrm{Si}$ and $\mathrm{Mg}$ atoms are very similar so they cannot be distinguished

Table 7

Polymorphs of tricalcium silicate and references related to structure determination.

\begin{tabular}{|c|c|c|c|c|c|c|}
\hline Temperature & Crystal system & Notation & ICSD codes & PDF codes & Year & Reference \\
\hline \multirow[t]{4}{*}{$1070^{\circ} \mathrm{C}$} & \multirow[t]{4}{*}{ Rhombohedral } & \multirow[t]{4}{*}{$\mathrm{R}$} & 22501 & 01-073-0599 & 1985 & Il'inets et al. [51] \\
\hline & & & 24625 & 01-085-1378 & 1984 & Nishi et al. [52] \\
\hline & & & 30889 & 01-073-2077 & 1952 & Jeffery [53] \\
\hline & & & 24452 & $16-406$ & 1950 & O'Daniel et al. [54] \\
\hline \multirow[t]{2}{*}{$1060^{\circ} \mathrm{C}$} & \multirow[t]{4}{*}{ Monoclinic } & $\mathrm{M}_{3}$ & 94742 & 01-070-8632 & 2002 & de La Torre et al. [33] \\
\hline & & & 64759 & 01-085-1378 & 1985 & Nishi et al. [55] \\
\hline $990{ }^{\circ} \mathrm{C}$ & & $\mathrm{M}_{2}$ & & & & no reference \\
\hline \multirow[t]{2}{*}{$980{ }^{\circ} \mathrm{C}$} & & $\mathrm{M}_{1}$ & - & - & 2006 & de Noirfontaine et al. [32] \\
\hline & \multicolumn{2}{|c|}{ Average monoclinic structure } & 81100 & 01-086-0402 & 1995 & Mumme [56] \\
\hline $920^{\circ} \mathrm{C}$ & Triclinic & $\mathrm{T}_{3}$ & 162744 & - & 2008 & de La Torre et al. [57] \\
\hline \multirow[t]{2}{*}{$620^{\circ} \mathrm{C}$} & & $\mathrm{T}_{2}$ & - & - & 2004 & Peterson et al. [58] \\
\hline & & $\mathrm{T}_{1}$ & 4331 & 01-070-1846 & 1975 & Golovastikov et al.[59] \\
\hline
\end{tabular}




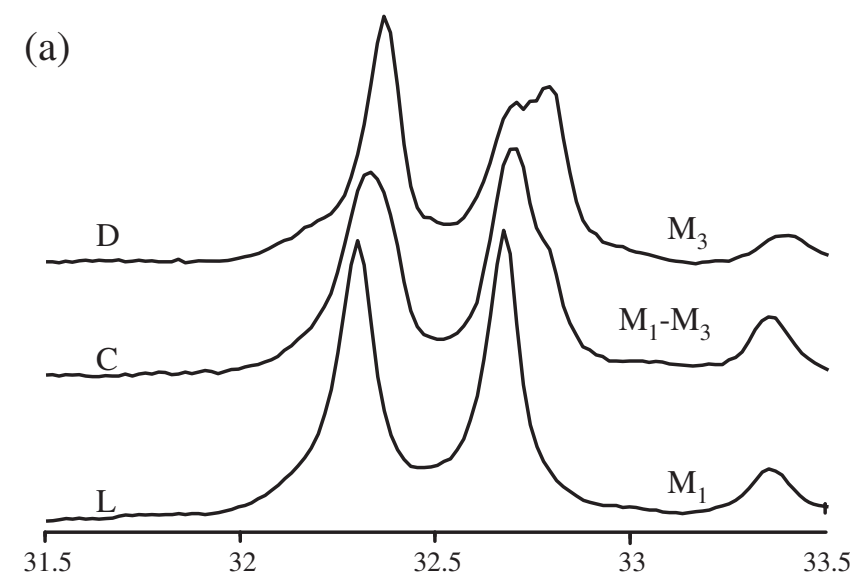

(b)

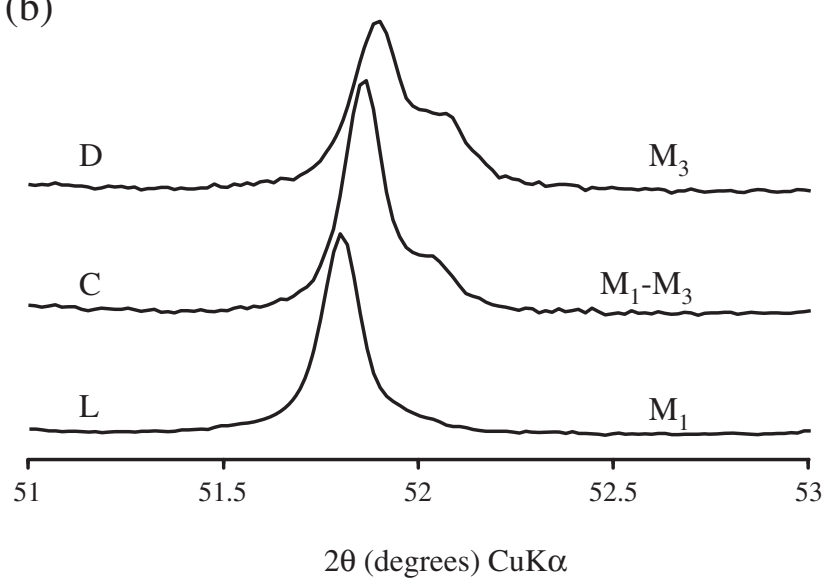

Fig. 1. Two angular window (a) $31.5^{\circ}-33.5^{\circ}$, (b) $51^{\circ}-53^{\circ}$ that permit to identify the $\mathrm{M}_{3}$ alite polymorph (cement $\mathrm{D}), \mathrm{M}_{3}+\mathrm{M}_{1}$ (cement $\mathrm{C}$ ) and $\mathrm{M}_{1}$ (clinker $\mathrm{L}$ ).

by direct refinement of site occupancies. The scattering factor for $\mathrm{Al}$ is used to represent the total occupancy of $\mathrm{Mg}+\mathrm{Al}+\mathrm{Si}$ and compared with $\mathrm{Mg}+\mathrm{Al}+\mathrm{Si}$ to $\mathrm{Fe}$ atomic ratio from EDS (labeled $\mathrm{EDS}^{2}$ in the figure, whereas EDS ${ }^{1}$ represents $\mathrm{Al}$ to $\mathrm{Fe}$ atomic ratio). The agreement between the $\mathrm{Al} / \mathrm{Fe}$ ratio of the refinement after selective dissolution $\mathrm{XRD}^{2}$ and the EDS analysis including Si and Mg EDS ${ }^{2}$ is pretty good. However it can be seen that without selective dissolution (not very practical on a routine basis) it is not possible to obtain an estimation of the $\mathrm{Al} / \mathrm{Fe}$ ratio consistent with the EDS from Rietveld refinement. The error introduced by not doing selective dissolution (difference between $X_{R D}^{1}$ and $X^{2} D^{2}$ ) is about $1 \mathrm{wt} \%$.

The refinement of the occupancy for the cements used in this study shows an occupancy factor of 0.5 to 0.7 for Fe in octahedral site $(0.3$ to 0.5 for $\mathrm{Al}$ ) and 0 to 0.2 for $\mathrm{Fe}$ in tetrahedral site ( 0.8 to 1 for $\mathrm{Al}$ ).

Table 8

Phase composition (wt.\%) and criteria of fit (R-Bragg factor $R_{B}$, R-structure factor $R_{F}$ ) for the cements $\mathrm{A}, \mathrm{C}$ and clinker $\mathrm{L}$ using $\mathrm{M}_{1}$ and/or $\mathrm{M}_{3}$ structural description. * Sum of $\mathrm{M}_{1}$ (14.5 wt.\%) and $\mathrm{M}_{3}$ (48.5 wt.\%).

\begin{tabular}{|c|c|c|c|c|c|c|c|c|}
\hline & & \multicolumn{3}{|c|}{$\mathrm{M}_{1}[32]$} & \multicolumn{3}{|c|}{$\mathrm{M}_{3}$ [33] } & \multirow{2}{*}{$\frac{\mathrm{M}_{1}+\mathrm{M}_{3}}{\mathrm{wt} . \%}$} \\
\hline & & wt.\% & $\mathrm{R}_{\mathrm{B}}$ & $\mathrm{R}_{\mathrm{F}}$ & wt.\% & $\mathrm{R}_{\mathrm{B}}$ & $\mathrm{R}_{\mathrm{F}}$ & \\
\hline \multirow{2}{*}{$\mathrm{D}\left(\mathrm{M}_{3}\right)$} & Alite & 65.9 & 5.4 & 2.4 & 66.4 & 3.0 & 1.4 & - \\
\hline & Belite & 14.9 & 3.7 & 1.8 & 16.7 & 2.2 & 1.2 & - \\
\hline \multirow[t]{2}{*}{$\mathrm{C}\left(\mathrm{M}_{1}-\mathrm{M}_{3}\right)$} & Alite & 62.8 & 4.7 & 2.1 & 62.6 & 2.9 & 1.3 & $63.8^{*}$ \\
\hline & Belite & 16.4 & 3.0 & 1.5 & 16.7 & 2.5 & 1.2 & 15.9 \\
\hline \multirow[t]{2}{*}{$\mathrm{L}\left(\mathrm{M}_{1}\right)$} & Alite & 66.3 & 5.1 & 2.8 & 65.4 & 5.4 & 2.3 & - \\
\hline & Belite & 14.4 & 3.7 & 2.1 & 15.2 & 4.5 & 2.1 & - \\
\hline
\end{tabular}
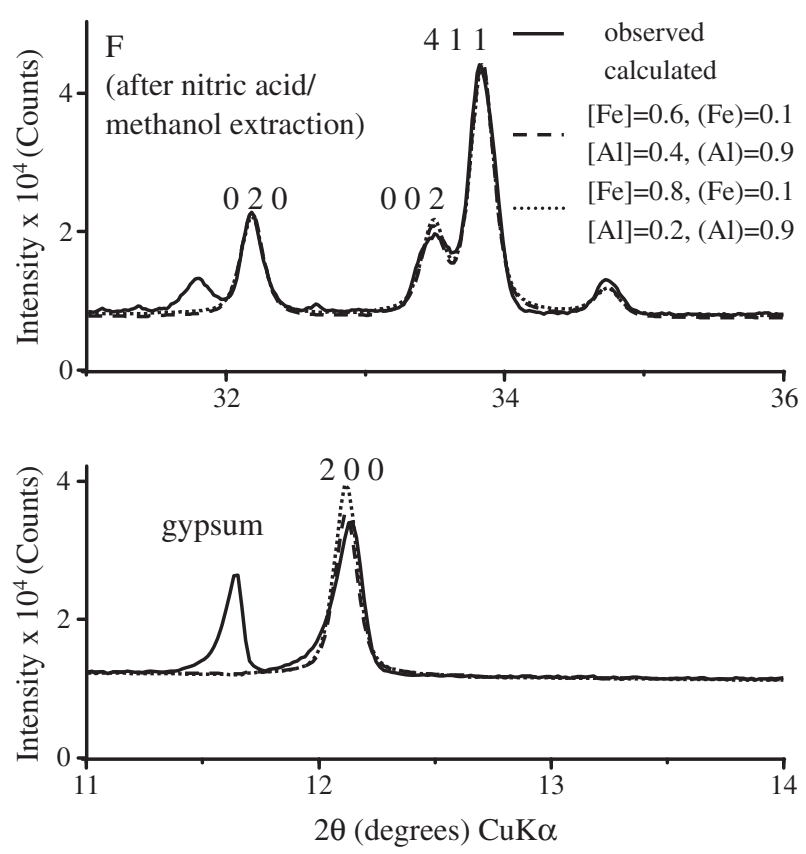

Fig. 2. Effect of variable occupancy factor on $\mathrm{Al}$ and Fe in tetrahedral ( ) and octahedral [ l sites on the simulation of ferrite phase obtained from cement $\mathrm{F}$ after nitric acid/ methanol extraction.

However Fe and $\mathrm{Al}$ can be substituted by many other cations such as $\mathrm{Mg}, \mathrm{Si}, \mathrm{Ti}, \mathrm{Mn}$ and data on the distribution of these substituents between octahedral and tetrahedral sites are insufficient to justify a distinction between them as the preferences of some of the cations especially $\mathrm{Mg}^{2+}$ in the structure are unknown [65].

\subsubsection{Refinement of the occupancy factor for other phases}

Even for the ferrite phase where we have a large scattering factor contrast between $\mathrm{Fe}$ and $\mathrm{Al}$ and knowledge of the crystallographic sites where substitution occurs, the refinement of the occupancy factor is not so easy. In other phases, it is quite unreasonable to refine occupancy factor or fix it according to EDS data. As an example, in alite, the Al to Si substitution has no influence on XRD pattern as their

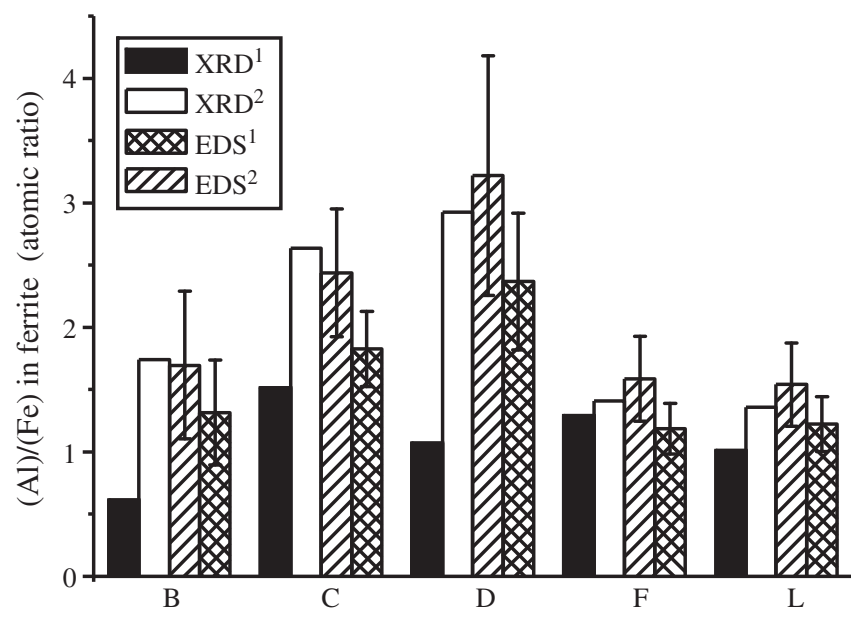

Fig. 3. Al to Fe atomic ratio in the ferrite phase deduced from Rietveld refinement of the ground cement $\mathrm{XRD}^{1}$, of the ground cement after selective dissolution of silicate phases $\mathrm{XRD}^{2}$, and from $\mathrm{EDS}^{1}$, adding $\mathrm{Si}$ and $\mathrm{Mg}$ to $\mathrm{Al}$ as explained in the text $\mathrm{EDS}^{2}$. 
scattering factors are very similar. Furthermore, the unit cell of $\mathrm{M}_{3}$ alite even approximated by simpler pseudo structure contains 54 sites for $\mathrm{Ca}$ and 18 for $\mathrm{Si}$ and we have no information on which crystallographic site substitution can occurs.

\subsection{Absorption contrast}

3.4.1. Results and absorption correction after refinement

After the refinement, the weight fraction $\mathrm{W}$ or volume fraction VF for the phase $\alpha$ in a mixture of p phases can be obtained from [66]:

$\mathrm{W}_{\alpha}=\frac{\mathrm{S}_{\alpha} \rho_{\alpha} \mathrm{V}_{\alpha}^{2}}{\sum_{\mathrm{p}} \mathrm{S}_{\mathrm{p}} \rho_{\mathrm{p}} \mathrm{V}_{\mathrm{p}}^{2}}$

$\mathrm{VF}_{\alpha}=\frac{\mathrm{S}_{\alpha} \mathrm{V}_{\alpha}^{2}}{\sum_{\mathrm{p}} \mathrm{S}_{\mathrm{p}} \mathrm{V}_{\mathrm{p}}^{2}}$

where:

$\mathrm{S}_{\alpha} \quad$ scale factor proportional to the number of unit cells contributing to the scattering divided by the unit cell volume, $\rho \quad$ X-ray density

$\mathrm{V} \quad$ unit cell volume.

\subsubsection{Effect of the density on quantification}

The cement phases are not pure phases but incorporate ions as depicted in Table 4 . These substitutions will affect the unit cell volume, and the density as well as the intensity of the diffracted lines through the structure factor. The unit cell dimensions of the phases are refined taking into account the effect of minor substitutions on the unit cell volume. As depicted by Eq. 4, the density is also used in the quantitative calculation of the weight fraction. The formula used for mass calculation of the unit cell is taken from the ICSD file (Table 6) and differs slightly from that indicated by the EDS compositions (Table 4). The difference in density between using ICSD and EDS formula is low for alite, belite, and aluminate phases (less than 0.02) and has no impact on the weight fraction calculated. For the ferrite phase, the difference is significant ( 0.1 to 0.2 ) due to the molar mass difference between iron and aluminium cations and the large solid solution of $\mathrm{Ca}_{4} \mathrm{Fe}_{(4-\mathrm{x})} \mathrm{Al}_{\mathrm{x}} \mathrm{O}_{10}$ ( $\mathrm{x}$ is fixed to 2 in the ICSD card). This leads to error in ferrite quantification of about $0.5 \mathrm{wt} . \%$, which could be incurred in cases when time consuming, complimentary EDS analyses are not available.

\subsubsection{Effects of absorption}

$\mathrm{X}$-ray radiation is absorbed by each phase to a different extent depending on its linear absorption (attenuation) coefficient $\mu$ (see Table 9). A powdered mixture behaves ideally when the average

Table 9

Linear absorption coefficient for CuK $\alpha$ radiation and Moh's hardness [84] for cement phases.

\begin{tabular}{lll}
\hline Phase & $\mu\left(\mathrm{cm}^{-1}\right)$ & Moh hardness \\
\hline Alite & 320 & 5.5 \\
Belite & 310 & 5.0 \\
Ferrite & 505 & $5-6$ \\
Aluminate & 272 & 6.0 \\
Lime & 423 & 3.5 \\
Calcite & 200 & 3.0 \\
Periclase & 102 & 6.5 \\
Quartz & 95 & 6.0 \\
Gypsum & 146 & 2.0 \\
Anhydrite & 230 & 3.5 \\
\hline
\end{tabular}

particle size is less than the critical value dictated by the phase with the highest absorption coefficient. The critical particle size is defined by Brindley [67] as a function of the absorption coefficient $\bar{\mu}$ and the particle diameter $d_{50}$ ( $50 \%$ of the total volume of particles are below the median size $\mathrm{d}_{50}$ ). Four categories of powders may be considered: fine $\left(\bar{\mu} d_{50}<0.01\right.$, the absorption effect is negligible), medium $(0.01<$ $\left.\bar{\mu} d_{50}<0.1\right)$, coarse $\left(0.1<\bar{\mu} d_{50}<1\right)$ and very coarse $\left(\bar{\mu} d_{50}>1\right)$. According to Brindley, for a medium powder $\left(0.01<\bar{\mu} d_{50}<0.1\right)$, the relative absorption of the different phases should be included in the weight fraction $\mathrm{W}$ after the Rietveld refinement by modifying the Eq. (4) [68]:

$\mathrm{W}_{\alpha}=\frac{\mathrm{S}_{\alpha} \rho_{\alpha} \mathrm{V}_{\alpha}^{2}}{\left.\tau_{\alpha} \sum_{\mathrm{p}} \frac{\mathrm{S}_{\mathrm{p}} \rho_{\mathrm{p}} \mathrm{V}_{\mathrm{p}}^{2}}{\tau_{p}}\right)}$

with

$\tau_{\alpha}=\frac{1}{\mathrm{~A}_{\alpha}} \int_{0}^{\mathrm{A}_{\alpha} \exp }\left[-\left(\mu_{\alpha}-\bar{\mu}\right) \mathrm{x}\right] d \mathrm{~A}_{\alpha}$

where $A_{\alpha}$ is the particle volume of the phase $\alpha, \mu_{\alpha}$ is the absorption coefficient of the phase $\alpha, \bar{\mu}$ the mean linear absorption coefficient of the solid matrix and $x$ the linear path inside the particle. The integral can be solved numerically for spherical particles but needs the mean particle diameter for every phase as input which is not accurately known. The phases in the clinker have similar absorption coefficients except for the ferrite and periclase phases where the effect may be significant. For a $\mathrm{CuK}_{\alpha}$ radiation, the absorption coefficient $\bar{\mu}=300 \mathrm{~cm}^{-1}$ usually observed for cementitious materials requires a particle size less than $3.5 \mu \mathrm{m}$. In general, the use of the Brindley correction in quantitative analysis is still controversial as it depends on the composition of the mix. In case of $\operatorname{LiF}\left(\mu=52 \mathrm{~cm}^{-1} \mathrm{CoK}_{\alpha}\right.$ radiation $) / \mathrm{Pb}\left(\mathrm{NO}_{3}\right)_{2}\left(\mu=1046 \mathrm{~cm}^{-1}\right)$ mixtures with particle radius around $5 \mu \mathrm{m}$, the Rietveld analysis of mixture with $45 \%$ weighed LiF gives 61.9\% without Brindley corrections and 45 wt.\% with [68]. In other cases, inappropriate use of the Brindley correction can be worse than using no such correction as shown in a recent quantitative phase analysis round robin [69]. Therefore the correction should only be used when phases with big absorption differences are present and their particle size known.

A comparison between laboratory XRD ( $\mathrm{CuK}_{\alpha}$ radiation) and synchrotron measurements $(\lambda=0.4)$ performed by de La Torre et al. [70] shows an underestimation of $\mathrm{C}_{4} \mathrm{AF}$ for all laboratory experiments in model mixtures of clinker ( $8.2 \%$ and $10 \mathrm{wt}$.\% of $\mathrm{C}_{4} \mathrm{AF}$ deduced from laboratory X-ray and synchrotron radiations respectively with no Brindley correction in a model mixture containing $10 \%$ of $\mathrm{C}_{4} \mathrm{AF}$ ). This underestimation has been attributed to microabsorption effect in their synthetic mixture where this effect is enhanced by large average particle size of $\mathrm{C}_{4} \mathrm{AF}(15 \mu \mathrm{m})$. As pointed out, this problem is not so important in commercial sample in which the particle size of this phase is small (around $1 \mu \mathrm{m}$ ). This has been shown in a recent study of the same team where the same amount of $\mathrm{C}_{4} \mathrm{AF}$ has been found using laboratory and synchrotron X-ray radiations (12.4 wt.\% and $12.1 \mathrm{wt} . \%$ $\mathrm{C}_{4} \mathrm{AF}$ respectively) in a commercial clinker [71]. Therefore no absorption correction was applied in this study as no important absorption differences are present and particle size of the different phases unknown.

\subsection{Peak shape function $\Phi$}

The powder diffraction profile is the convolution of the peak profiles separately produced by instrumental and specimen broadening sources. In the empirical approach, the peak shape is described 
by a pseudo-Voigt function that consists of a simple linear combination of Lorentzian L and Gaussian G functions:

$\Phi\left(\Delta \theta_{\mathrm{iK}}\right)=(1-\eta) \mathrm{G}\left(\Delta \theta_{\mathrm{iK}}, \mathrm{H}_{\mathrm{K}}\right)+\eta \mathrm{F}\left(\Delta \theta_{\mathrm{iK}}, \mathrm{H}_{\mathrm{K}}\right)$

where:

$\eta \quad$ pseudo-Voigt mixing parameter, $\mathrm{H}_{\mathrm{K}} \quad$ Full Width at Half Maximum (FWHM)

The variation of the FWHM of the Gaussian and Lorentzian components are both modelled with the function described by Caglioti et al. [72]:

$\mathrm{H}_{\mathrm{K}}^{2}=\mathrm{U} \tan ^{2} \theta_{K}+\mathrm{V} \tan \theta_{K}+\mathrm{W}$

where $\mathrm{U}, \mathrm{V}, \mathrm{W}$ are refinable parameters.

The fundamental parameters approach (FPA) is based on a comprehensive description of the instrument [73]. The resultant peak shape is then obtained by a convolution of the modelled instrumental function with the sample pseudo-Voigt function. Then, if the instrument is well characterized, line broadening can be analysed without a reference specimen although the presence of a monochromator and/or mirrors for the FPA approach may be problematic as at the moment there is no satisfactory solution, based on a physically meaningful model, for incorporating such devices during the calculation of the instrumental function [74]. The FPA approach is implemented in several software products as TOPAS [75]. For the quantitative analysis of cement, the comparison between these two approaches leads to very similar results ([76] and comparison shown in figure where the two different approaches are used). We can also mention a third approach for the peak profile analysis based upon a fundamental microstructural parameters dedicated to nanocrystalline and deformed systems as kaolinite where the Rietveld method is not applicable [77].

In the present study, we have used the empirical approach. As pointed out by Roode-Gutzmer et al. [21], $\eta$ between 0.6 and 0.7 works best for Bragg-Brentano X-ray diffraction patterns acquired in step scan mode for powdered specimens of Portland cement clinkers using $\mathrm{CuK}_{\alpha}$ radiation. In practice for cement analysis, only the $\mathrm{W}$ parameter is refined in the main phases while the others are kept constant $(\eta=0.6, U=V=0)$ in order to reduced the number of refined parameters. Due to the peak overlap in the X-ray pattern of cement, the refinement of the $\mathrm{W}$ parameter is generally sufficient to describe relatively well the peak shape of phases with high concentrations. Additional parameters can be included in the refinement of the peak shape to take into account the asymmetry of low angle peaks due to the axial divergence (see [78] for details). For example, this asymmetry can be clearly observed in the peak of the ferrite phase at around $12^{\circ}$ in Fig. 2 however the impact on quantitative analysis for anhydrous cement where the ferrite phase is present in relatively low amounts ( $<15 \mathrm{wt} . \%)$ will not be large.

For highly overlapped diffraction patterns such as alite and belite, problems may arise in the refinement of peak shapes. However, as previously noticed by Pritula et al. [79] and also observed in our refinement, although the patterns of alite and belite are similar, the correlation matrix does not reveal significant correlation between $\mathrm{W}$ and scale factor parameters of alite and belite.

\subsection{Influence of sample preparation}

The preparation of samples for X-ray diffraction is recognized to be the first key step for quantitative analysis $[80,81]$. The aims of the sample preparation are:

- to obtain a number of crystallites contributing to each reflection to be sufficiently large to obtain peaks of reproducible intensity and avoid spotty lines (see some Debye-Scherrer photographs in [82]),

- to reduce the preferred orientations of the crystallites (see Section 3.5).

The grains are prone to orientation due to cleavage and crystal habit. Using powder that is too coarse can give rise to inaccurate and imprecise intensities of the peaks and so affect the quantitative results. As a general rule, for accurate X-ray diffraction intensities from a powder sample, the particle size should be at most $10 \mu \mathrm{m}$ and preferably smaller [80]. As shown in Fig. 4 for the cement C, the median sizes $d_{50}$ deduced from the cumulative distribution for the investigated samples are around $15 \mu \mathrm{m}$. On this basis, the particle sizes of as received cement are too large for quantitative X-ray analysis and cements should be ground to achieve the recommended particle size. However, the results shown in Fig. 5 indicate that for the cements studied here, grinding to $\mathrm{d}_{50}$ around $4 \mu \mathrm{m}$ only slight effects are observed in the quantitative results of both minor and main phases. We should mention that we also performed a $360^{\circ}$ rotation of the specimen during acquisition in order to obtain a better statistic [82] (the rotation will not affect the preferred orientation). These results are in good agreement with the recent work of Mitchell et al. [83] performed on NIST SRM 637 Portland cement except for $C_{3} A$ where a systematic underestimation of about $0.6 \mathrm{wt} . \%$ for unmicronized samples is observed. They can also observe for unmicronized sample large errors in the quantification of periclase present as large grains in their clinker.

Even if the grinding has a little influence on the quantitative results for the cement investigated in the present study, as the textures and crystallite sizes of the constituent minerals in clinker vary to a considerably extent with the processing conditions, grinding is strongly recommended.

It is especially the case when some laboratory model mixtures as the addition of gypsum to clinker are done in order to validate the control file. One should note try to correct heterogeneity-based intensity errors (spottiness) by applying a preferred orientation correction.

As cement contains minerals with different hardness (Table 9) and alite is more brittle than belite due to more pronounced cleavage; grinding leads to the concentration of brittle and softer minerals (gypsum, alite) in the finer fraction and harder phases (belite) in the coarser fraction. This was demonstrated previously by Gutteridge [85] and is shown for the cement A in Table 10. For this reason ground samples should not be sieved.

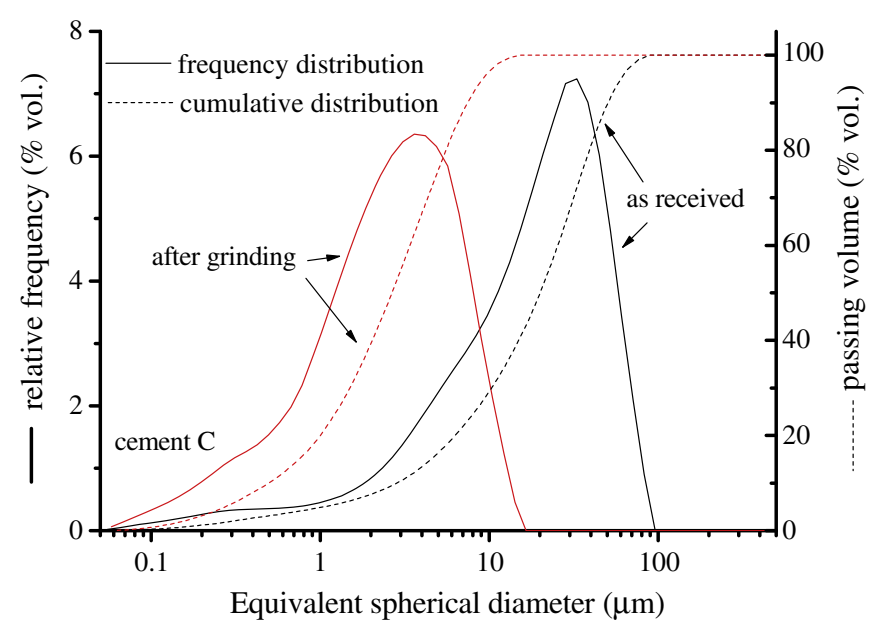

Fig. 4. Frequency and cumulative distributions of the cement $C$ as received and after grinding. 

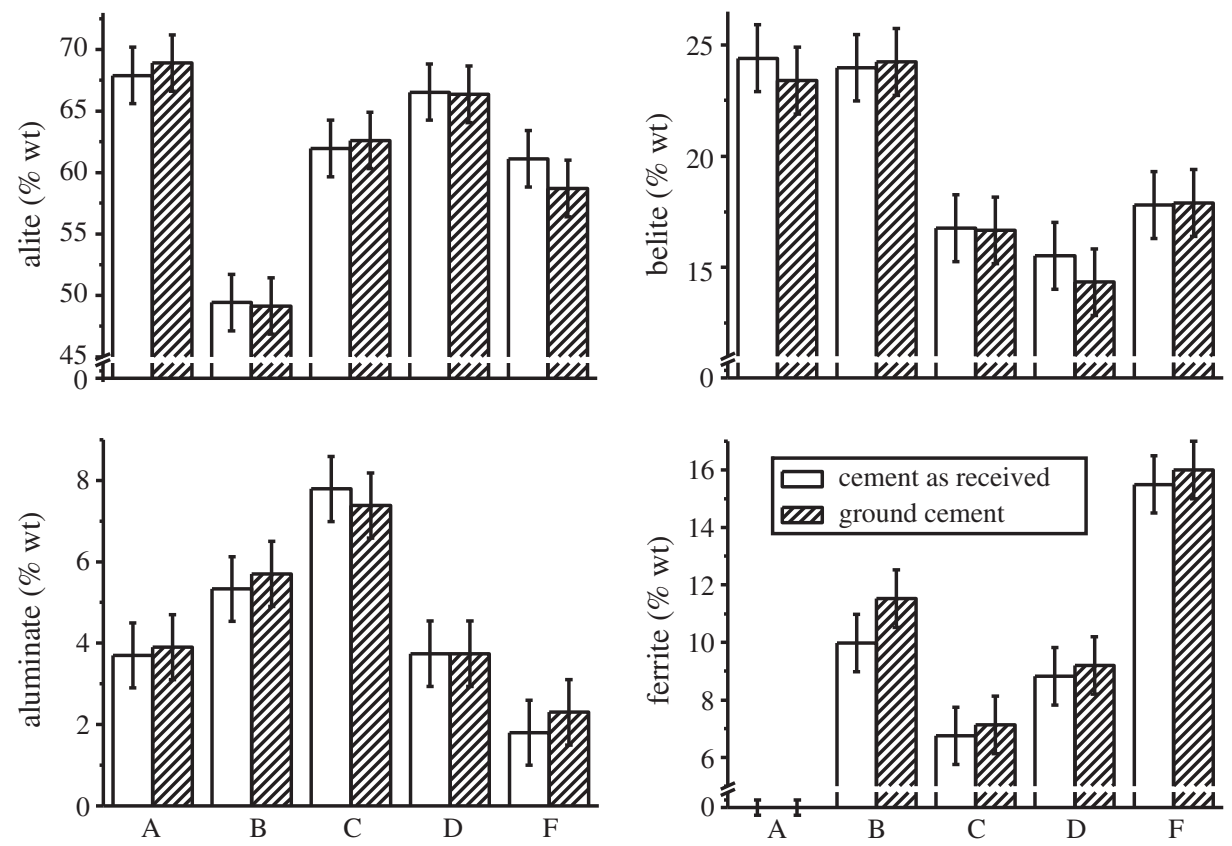

Fig. 5. Amount of the main anhydrous cement phases deduced by QXRD in cement as received and ground cement.

Wet milling is recommended as this significantly increases the efficiency of grinding by uniformly reducing the particle size of the hard materials, while not overgrinding the softer ones [80]. The liquid also ensures that the sample does not compact into the corners of the milling jar and prevents mill coating. Indeed, it was not possible in this study to obtain a particle size below $10 \mu \mathrm{m}$ by dry grinding the resulting diffractogram having broad peaks with reduced intensity, due to loss of crystallinity and the strains induced by overgrinding. By extensive grinding, we can observe the transformation of gypsum into bassanite and anhydrite by loss of water and then the X-ray amorphisation of sulphate phases [86,87]. Solid state reaction of $\mathrm{CaCO}_{3}$ (polymorphic change of aragonite to calcite) due to overgrinding has also been reported $[80,81]$.

In the method employed in this study, no decomposition of gypsum or calcite was observed but there was a slight line broadening, which may occur for crystallite sizes below $1 \mu \mathrm{m}$, when the line breadth becomes significantly broader than the inherent instrumental peak breadth but the integrated intensity remains the same [88].

\subsection{Preferred Orientation $(P O)$ function $P$}

Cleavage or growth mechanisms of some crystals may lead to preferentially orientation in a particular crystallographic direction when the powder is compacted in the sample holder. This process may modify the intensities of the diffracted peaks and should be taken into account during the Rietveld refinement (see Eq. 1). According to Dollase [89], the texture or PO can be modelled by a single pole-

Table 10

Changes in the composition of cement A using various sieve grading.

\begin{tabular}{lccclll}
\hline Cement A & $\begin{array}{l}\mathrm{d}_{10} \\
(\mu \mathrm{m})\end{array}$ & $\begin{array}{l}\mathrm{d}_{50} \\
(\mu \mathrm{m})\end{array}$ & $\begin{array}{l}\mathrm{d}_{90} \\
(\mu \mathrm{m})\end{array}$ & $\begin{array}{l}\text { Alite } \\
(\text { wt.\%) }\end{array}$ & $\begin{array}{l}\text { Belite } \\
(\text { wt.\%) }\end{array}$ & $\begin{array}{l}\text { Aluminate } \\
(\text { wt.\%) }\end{array}$ \\
\hline As received & 1.2 & 9.7 & 25.4 & 68.9 & 23.4 & 3.9 \\
Sieved $>2 \mu \mathrm{m}$ & 2.9 & 12.3 & 30.8 & 63.1 & 29.7 & 3.7 \\
Sieved $>10 \mu \mathrm{m}$ & 14.6 & 29.6 & 52.2 & 51.5 & 40.5 & 4.1 \\
\hline
\end{tabular}

density profile with a relatively simple functional form $P_{k}$ using the March coefficient as a refinable parameter:

$\mathrm{P}_{\mathrm{K}}=\left(\mathrm{R}^{2} \cos ^{2} \alpha_{\mathrm{k}}+\mathrm{R}^{-1} \sin ^{2} \alpha_{\mathrm{k}}\right)^{-\frac{3}{2}}$

where:

$\mathrm{R} \quad$ March coefficient (index of the extent of PO equal to unity for an ideal random powder sample),

$\alpha_{K} \quad$ angle between the PO direction and the normal to crystallites.

Another approach for preferred orientation correction by means of spherical harmonics $(\mathrm{SH})$ has been proposed for powder diffraction [90]. It was found that quite large corrections could be applied successfully compared to the March-Dollase correction. However, the $\mathrm{SH}$ model is not so straightforward and should be applied on phase present in large amount as shown by de La Torre in the case of gypsum [45].

In the case of cementitious materials, PO may often occur in alite, gypsum, anhydrite, hemihydrate, calcite, and dolomite. The visual recognition of the extent of $\mathrm{PO}$ in calcite is more problematic as the main peak affected by PO at $29.41^{\circ}\left(\begin{array}{lll}1 & 0 & 4\end{array}\right)$ overlaps with a peak of alite. A simple way to detect PO in most cases is to try different loading method for sample preparation and compared diffractograms. The vertical loading was performed by fixing a glass slide to the front surface of the XRD sample holder and then loading the material through the gap between the slide and holder by tapping with a spatula. This technique is highly reproducible and considerably reduces PO in most cases $[80,91]$. However, the vertical loading technique is time consuming and a good compromise may be the use of the backloading technique [92]. The use of a hydraulic press for defined pressure leads to XRD data independent of the operator and high reproducibility.

The effects of loading and preferred orientation refinement on quantitative analysis are shown in Fig. 6. Correct determination of calcite in the mix is achieved by the vertical and backloading methods with PO correction. For vertical loading, the March coefficient is 


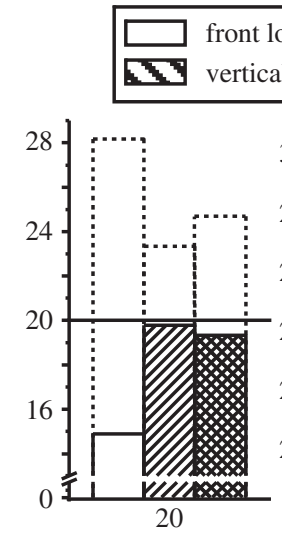

loading
al loading
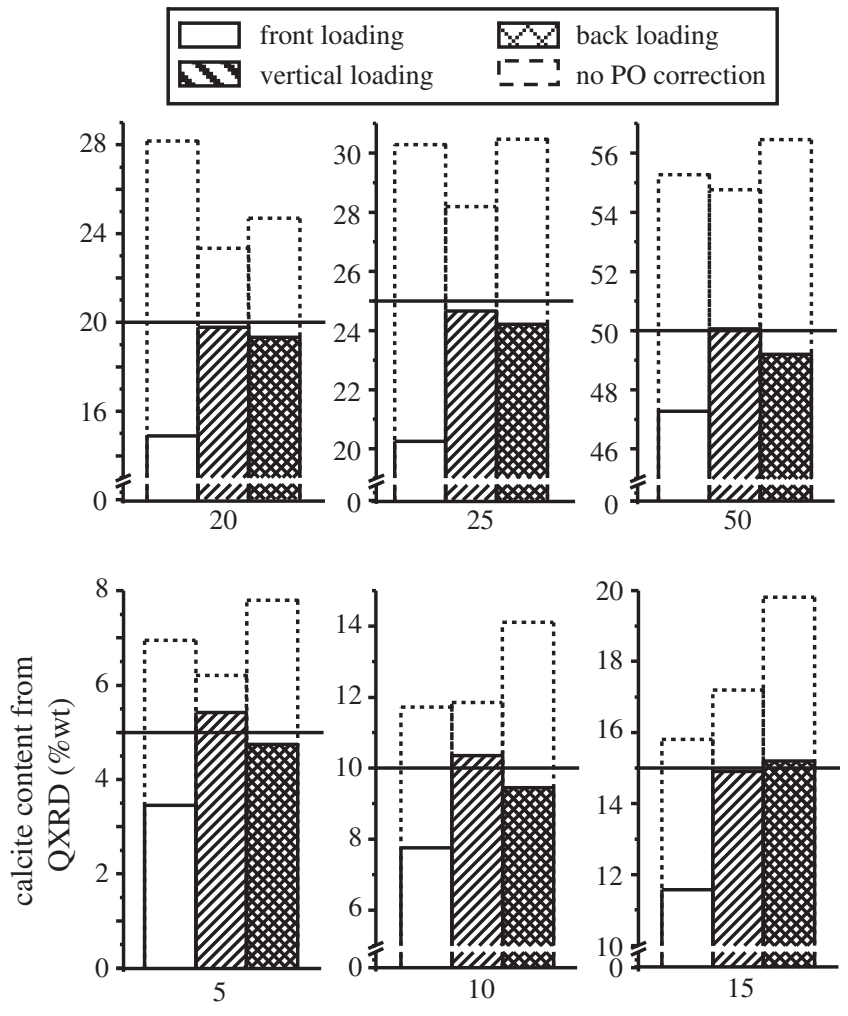

calcite content in the mix (\%wt)

Fig. 6. Effect of packing methods on preferred orientation in a clinker containing 5 to $50 \mathrm{wt} . \%$ of calcite.

around $0.93+/-0.02$ for the calcite peak and $0.83+/-0.03$ for back loading whereas it can be up to 0.74 for the front loading preparation. The front loading preparation is not very reproducible even for the same operator. For strong PO (March coefficient $<0.8$ ), the quantification of calcite is poor, even when a PO correction is made. However, we should note that even with strong preferred orientation, Enders suggests an empirical solution to find the optimum correction factor of preferred orientation for gypsum in cement based on spiking experiment where a known amount of gypsum is mixed with a cement [86].

\subsection{Selective dissolution}

As previously described by Stutzman [93], selective extractions may improved detection limits for identification and quantitative measurements. Two selective extractions (see [64] for procedure details) are particularly important for the Rietveld analysis:

- the quantitative salicylic acid/methanol extraction (SAM) that dissolve silicate phases and free lime,

- the potassium hydroxide/sugar extraction $(\mathrm{KOH} /$ sugar) that dissolves the aluminate and ferrite phases.

The Rietveld analysis permits a very precise quantification of $\mathrm{C}_{3} \mathrm{~A}$ cubic to orthorhombic ratio in model mixture [94]. The orthorhombic $\mathrm{C}_{3} \mathrm{~A}$ shows a splitting of the strong peak at $33.3^{\circ}$ of the cubic form into a strong singlet at about $33.2^{\circ}$ and a weaker, close doublet at $32.9^{\circ}$ $33^{\circ}$. For cement where the amount of $C_{3} A$ is in the range 5 to $15 \mathrm{wt} . \%$, the precise determination of the ratio is reached using the SAM extraction. As shown in Fig. 7 for the cement B, the ratio can be easily deduced from the refinement of the diffractogram obtained for the sample after SAM dissolution. This ratio, as well as the aluminate to ferrite ratio, can be kept constant during the final refinement. It
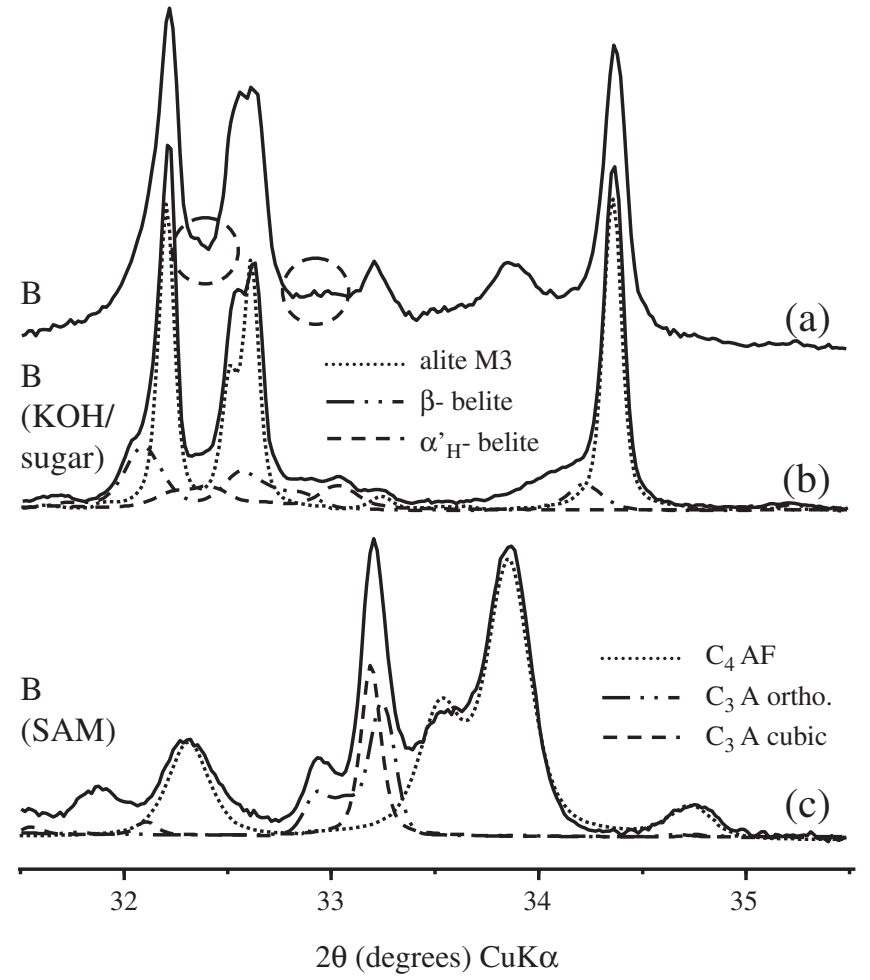

Fig. 7. Diffraction pattern of the cement B as received (a), after a KOSH treatment (b) and after a SAM treatment (c). Dash curves represent the pattern of some phases after Rietveld refinement.

should be stressed that the SAM extraction is quantitative and the loss of mass of alite and belite should match the Rietveld analysis. We can notice that the $\mathrm{KOH} /$ sugar treatment (Fig. $7 \mathrm{~b}$ ) reveals the presence of some peaks at around $33.5^{\circ}$ in the characteristics range of $C_{3} A$ even after dissolution of the aluminate phases. Furthermore, the SAM treatment (Fig. 7c) indicates a lower amount of $\mathrm{C}_{3} \mathrm{~A}$ in the orthorhombic form compared to the cubic one than calculated by the Rietveld analysis directly applied on the raw material. These features are explained by the presence of $\alpha^{\prime}{ }_{\mathrm{H}} \mathrm{C}_{2} \mathrm{~S}$ that exhibits peaks at around $32.5^{\circ}$ and $33.1^{\circ}$ which are respectively masked by reflections of alite, $\beta-C_{2} S$ and orthorhombic $C_{3} A$. In the Rietveld refinement of the cement $B$ without taking into account $\alpha^{\prime}{ }_{H^{-}} C_{2} S$, the unit cell parameter $b$ of the orthorhombic $C_{3} A$ is unusual: $b=15.308$ compared to 15.105 for the initial value. The large value of $b$ leads to a broad peak that "replace" the $\alpha^{\prime}{ }_{\mathrm{H}} \mathrm{C}_{2} \mathrm{~S}$ peak at $33.1^{\circ}$. Obviously, if constraints are present in the control file, $b$ reached one of them. Therefore it is recommended to have a function in the control file that alerts the user when a constraint is reached. The introduction of the $\alpha^{\prime}{ }^{-}{ }^{-} C_{2} S$ in the control file of the cement $B$ has an impact on the quantitative analysis. The amounts vary from $24.7 \mathrm{wt} . \%, 0 \mathrm{wt} . \%$, 3.5 wt.\% to $17.8 \%, 5.9 \%$ and $2.2 \%$ for $\beta-C_{2} S, \alpha^{\prime}{ }^{-} C_{2} S$, orthorhombic $C_{3} A$, respectively. The presence of $\alpha^{\prime}{ }_{\mathrm{H}}-\mathrm{C}_{2} \mathrm{~S}$ in some clinkers has been previously reported and its stabilization may be explained by high alkali content and rapid quenching [28]. It is noted that cement B has the highest $\mathrm{Na}_{2} \mathrm{O}_{\mathrm{eq}}$ content (see Table 1).

As illustrated for the cement D in Fig. 8b, the SAM treatment reveals minor phases as sulphates and permits also to fix the unit cell and shape parameters of the minor phases in the final refinement of the cement D. We can notice that for the aphthitalite, the unit cell parameters depend strongly on the $\mathrm{K}$ to $\mathrm{Na}$ ratio [29] and indicate which ICSD file to select. Without dissolution, the quantitative analysis of the minor phases may be doubtful due to the low signal and peak overlap. We can also notice in some cases the presence of portlandite. However, the portlandite shows usually in anhydrous 


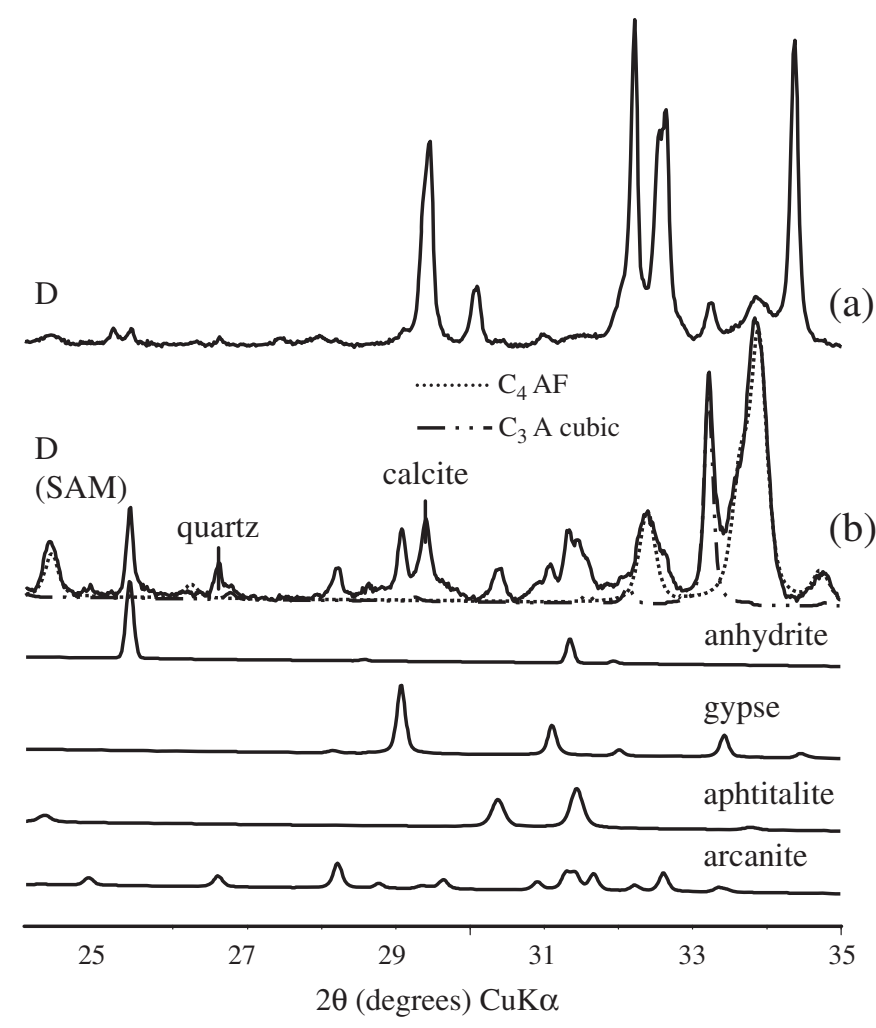

Fig. 8. Diffraction pattern of the cement $\mathrm{D}$ as received (a) and after a SAM treatment (b). Dash curves represent the pattern of some phases after Rietveld refinement. Sulphate phases after Rietveld refinement are presented below $\mathrm{b}$.

cement a large peak due to small crystallite size or poor ordering. The large breadth combined with a small intensity may affect the bias of the calculated amount.

This approach to obtain precise composition may be of utmost importance especially if the Rietveld analysis is used as input in mass balance calculations [95]. In the industrial context, the selective dissolution is not possible in the process however improvement of the sample preparation shows a good reproducibility and accuracy [96]. It should be stressed that it is rather more a statistical approach that is needed to detect some variations of the mineralogy during the process rather than a very precise composition of a particular sample [14].

\subsection{Precision of the Rietveld method}

In the present study as well as in the round robin studies, the potential amorphous content in the cement is neglected as modern clinker does not contain significant quantities of glass, except in rare cases [29]. The presence of high quantity of amorphous may lead to some errors in the reverse Bogue calculation or in the comparison of QXRD analysis with others methods as SEM or NMR.

\subsubsection{Standard deviation}

Until the introduction of whole pattern fitting, the results of the round robins on quantitative powder diffraction applied to cement show very poor reproducibility. As an example, the standard deviation and the maximum difference for alite, deduced from eight interlaboratory studies on six cement reported by Aldridge [97] in 1982, were respectively around 7.5 and $20 \mathrm{wt} . \%$. In these studies internal standard-based, peak area measurement methods were used. More recently, whole pattern approach as Rietveld analysis shows an improvement in both within and between laboratory repeatability and reproducibility. The results of 2003 and 2004 ASTM round robin reported by Stutzman et al.[5] deduced from eleven inter-laboratory studies on four NIST cements show a standard deviation between laboratory and a maximum difference for alite respectively of 2.3 and $6.2 \mathrm{wt} . \%$ (in this round robin, samples were previously ground under $10 \mu \mathrm{m}$ and no microabsorption corrections were done). Slightly higher standard deviations were found in the last round robin (see Table 2). To check the reproducibility of our measurements, samples A-D were sent with no preparation and indications to another laboratory. In Fig. 9, we report the difference in phase amount between the two laboratories performed in this study and the $95 \mathrm{wt} . \%$ reproducibility $\mathrm{R}$ of the round robin ASTM04 [5]. The observed difference do not exceed the $95 \mathrm{wt}$.\% reproducibility $\mathrm{R}$ of the round robin. Even if the absolute error for phases containing sulphate (gypsum, hemihydrate, anhydrate, arcanite) is quite low, the relative error is important. The main difference is for the cement $B$ and may be explained by the presence of $\alpha_{H}^{\prime}$ belite.

It should be stressed that the Rietveld analysis will not give an absolute analysis of a Portland cement clinker, the analysis is only relative to the standards or methods used for the calibration of the control file. Then, in inter-laboratory studies, it is not the accuracy of the analysis but the variability of the control files and sample preparation which is being examined. Round robins $[5,6]$ were dedicated to assess the accuracy of the Rietveld analysis by mixing suitably synthesized phases in appropriate proportions. From this, the difference with "true mineralogical percentage" (bias) can be established. The bias may reach $-4.7 \mathrm{wt} . \%$ for alite; $6.3 \mathrm{wt} . \%$ for belite (we can noticed that in all 6 mixtures except one the alite is overestimated and belite underestimated), -0.9 wt.\% for aluminate; -2.4 wt.\% for ferrite; 0.6 wt.\% for gypsum and 1.2 wt.\% for calcite.

\section{Guidelines for Rietveld analysis used in the laboratory}

We present in the Fig. 10 a scheme of the general guideline for Rietveld analysis applied to anhydrous cement used in our laboratory. We supposed that a control file has been developed and restraints imposed mainly on unit cell and shape parameters. Parameters for data acquisition (for examples angular aperture of the slit, step size, acquisition time) are also supposed optimized and lead to few thousands counts for the strongest peaks. In the case of fundamental parameter approach, the fundamental parameters dedicated to the instrument have not to be refined and restraints are imposed on strain and size parameters.

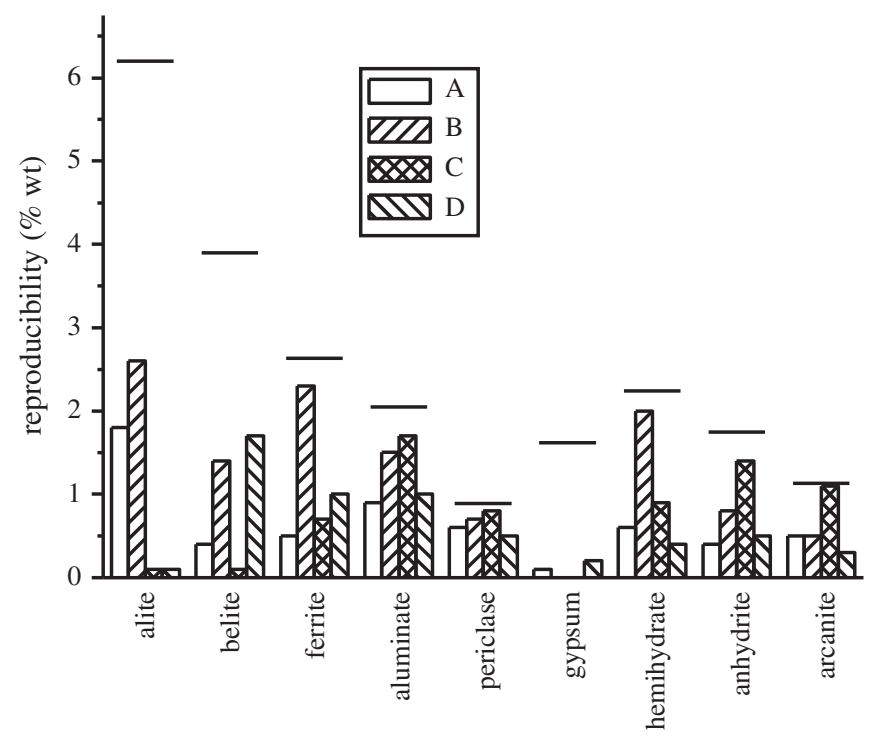

Fig. 9. Difference in phase amount between the two laboratories performed in this study (columns) and the $95 \mathrm{wt} . \%$ reproducibility R of the round robin ASTM04 [5] (lines). 


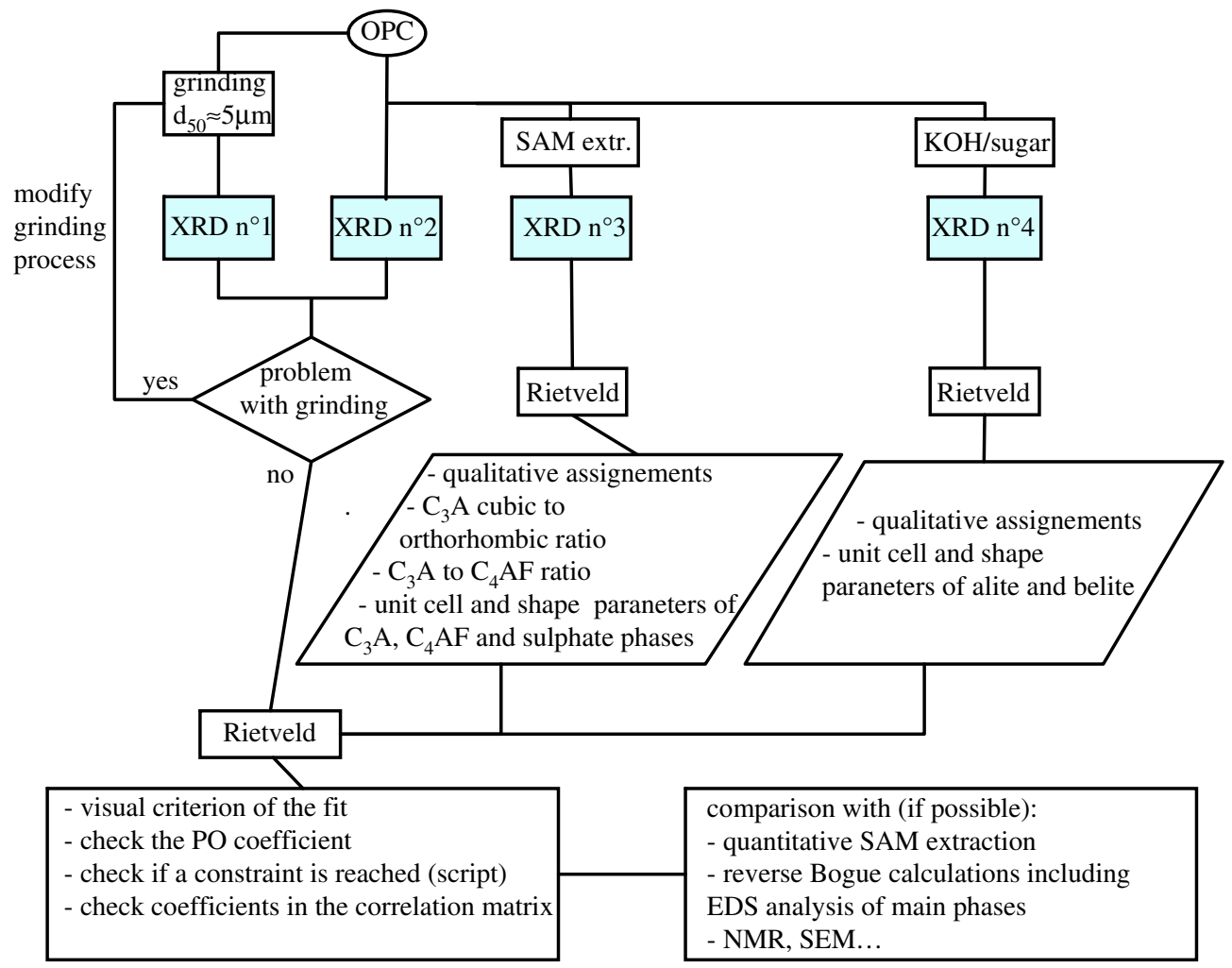

Fig. 10. Guidelines for Rietveld analysis of anhydrous OPC.

The refined parameters are the specimen displacement, the background coefficients, the scale factors and the lattice parameters in all cases.

\section{Comparison with other methods}

As previously mentioned, the Rietveld analysis will not give an absolute analysis of a Portland cement clinker, the analysis is only relative to the standards or methods used for the calibration of the control file. Therefore we compared the results obtained by Rietveld with different Bogue calculations; point counting using SEM and NMR [98] as these methods give independent assessments of the relative amounts of phases.

\subsection{Bogue and reverse Bogue calculation}

The most widely used method of estimating the potential phase composition of OPC from the oxide analysis was developed by Bogue [1]. However the Bogue calculation gives inaccurate results because the phases do not have the compositions that are assumed. In order to take into account the modification of the compositions of the major phases due to minor elements, modified Bogue calculation was proposed by Taylor [2]. The origins of these calculations, their uses and limitations have been described by Sorrentino et al. [3].

The first source of error is that small errors in chemical analysis are magnified by the Bogue calculations. In the Table 1, we report the standard deviation (SD) for XRF analysis. These errors are typical of inter-laboratory variation for chemical analysis of cement [99]. Two sets of analyses for our samples were made in two different laboratories and give results within these error bars. As an example, for the cement $\mathrm{B}$, two laboratories give for $\mathrm{CaO}$ respectively an oxide amount of $61.3 ; 61.7$ wt.\% and $20.5 ; 20.1$ wt.\% for $\mathrm{SiO}_{2}$. Keeping the rest of oxides amount equal for the set of data, the amount of alite increases by $5 \mathrm{wt} . \%$ and the amount of belite is reduced by $5 \mathrm{wt} . \%$.
The second source of error is the departure from the assumed composition. The compositions of the main phases in the cement A-L are given in Table 4. The atomic weight of $\mathrm{K}, \mathrm{Na}, \mathrm{Ca}, \mathrm{Mg}, \mathrm{Fe}, \mathrm{Al}, \mathrm{Si}$ and $\mathrm{S}$ were measured by EDS ( $\mathrm{K}$ and $\mathrm{S}$ are not reported due to their low content). The composition is expressed in terms of the parent structural formula units: for alite $\mathrm{Ca}_{3} \mathrm{SiO}_{5}$ normalizing the atomic composition to 5 atoms, for belite to 4 atoms (although it may be possible that vacancies occur in the oxygen sites for belite), for aluminate to 6 atoms and for ferrite to 5 atoms. As reported by Taylor [29], the significant substitutions in alite are of $\mathrm{Na}^{+}, \mathrm{K}^{+}, \mathrm{Mg}^{2+}$ and $\mathrm{Fe}^{3+}$ for $\mathrm{Ca}^{2+}$ and of $\mathrm{Al}^{3+}$, (less significant: $\mathrm{P}^{5+}, \mathrm{S}^{6+}$ ) for $\mathrm{Si}^{4+}$. These cation sums reported in the table are always very close to the stoichiometric values of the parent tricalcium silicate. A similar approach is shown for the other phases.

The comparison between Bogue calculation, modified Bogue calculation using composition reported in Table 4 and Rietveld analysis are presented in Fig. 11. As the modified Bogue calculation requires a matrix inversion, the error bars cannot be easily deduced from XRF and EDS errors. The error bars on the modified Bogue calculation presented in Fig. 11 are calculated by using the standard deviation of XRF measurements and do not take into account the error on EDS data. For our cements, the uncertainty on XRF measurements has much more impact on the error bars than the uncertainty on EDS data. Despite the large potential errors the agreement between modified Bogue calculation and Rietveld analysis is quite good. It is clear that the modified Bogue calculation gives a much better estimation of the real composition than the traditional Bogue, especially for cement $\mathrm{D}$ and $\mathrm{L}$ due to the departure from the assumed composition.

In the reverse Bogue calculation, we calculate the elemental oxide composition from phase content deduced by Rietveld analysis. As for the modified Bogue calculation, the phase composition and the standard deviation of EDS measurements are used in the elemental composition calculation and the associated error bars. If phase 

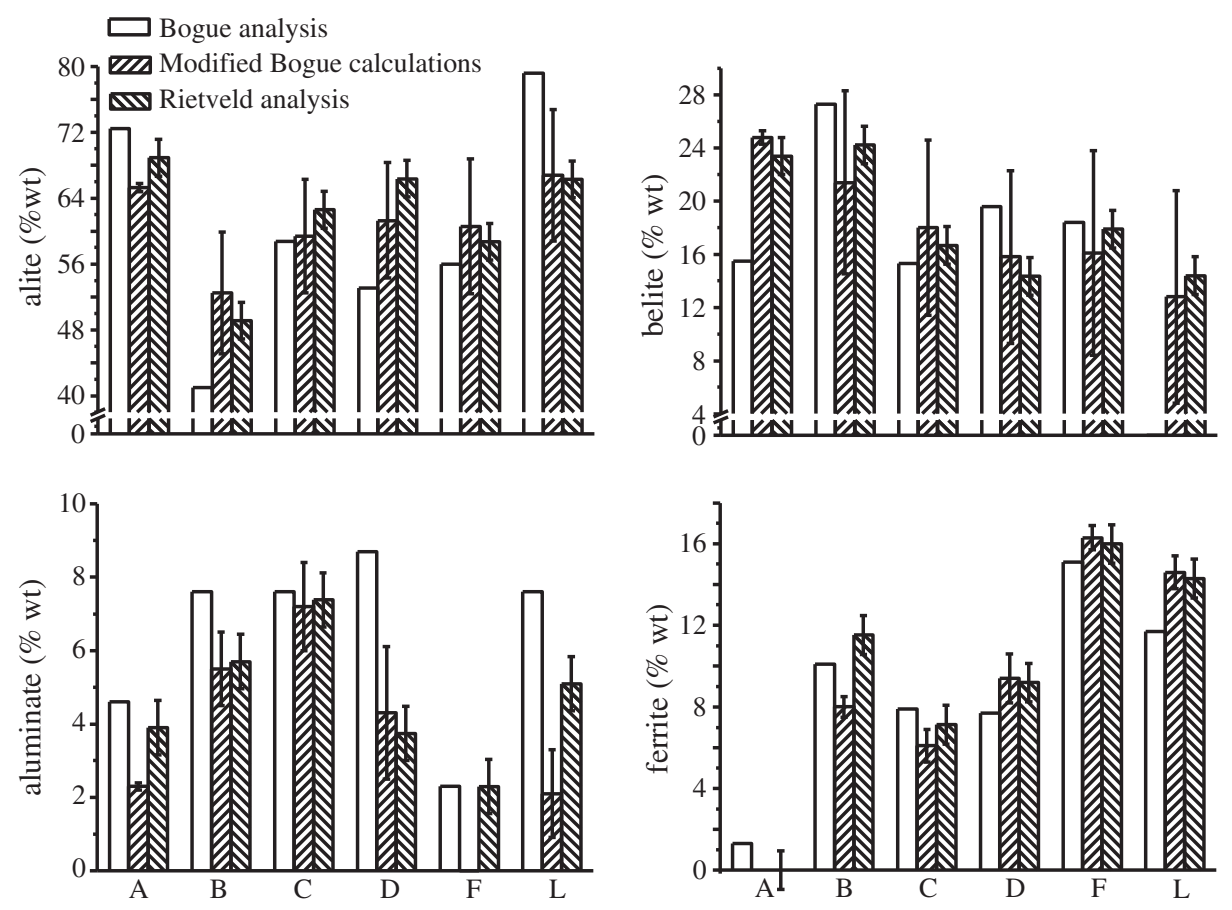

Fig. 11. Comparison of the results achieved by Bogue, Modified Bogue calculations and Rietveld quantification. The error bars on modified Bogue calculation are calculated by modifying the phase composition using the standard deviation of EDS measurements and do not take into account the error on XRF data.

compositions are not available then extreme values for substitution in phases can be used to establish the error bars. However this leads to large errors, for example $+/-2 \mathrm{wt} \%$ for $\mathrm{CaO}$ instead of $+/-0.9$ if we used EDS data then the comparison will not be so useful to detect any problem in the Rietveld quantification. We can see in Fig. 12 that there is a good agreement between calculated oxide compositions from Rietveld analysis and XRF.
5.2. Scanning electron microscopy (SEM) and ${ }^{29}$ Si nuclear magnetic resonance (NMR)

Scanning electron microscopy was used to determine the alite to belite volume ratio in the cements using the point counting method. By SEM, the ratio of the area of alite to belite is a consistent estimate of the volume ratio [100]. It can be directly compared with the volume
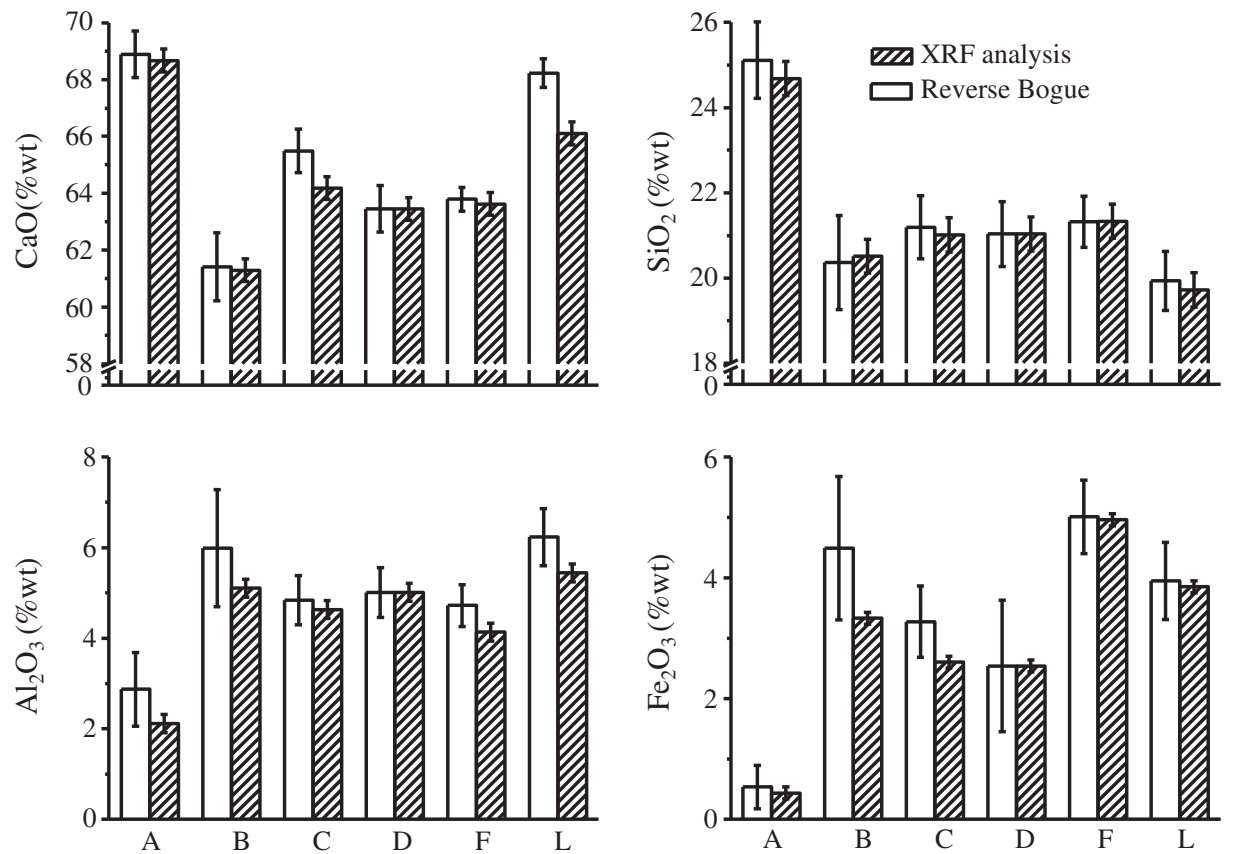

Fig. 12. Comparison of the results achieved by Reverse Bogue calculation and XRF elemental composition. 

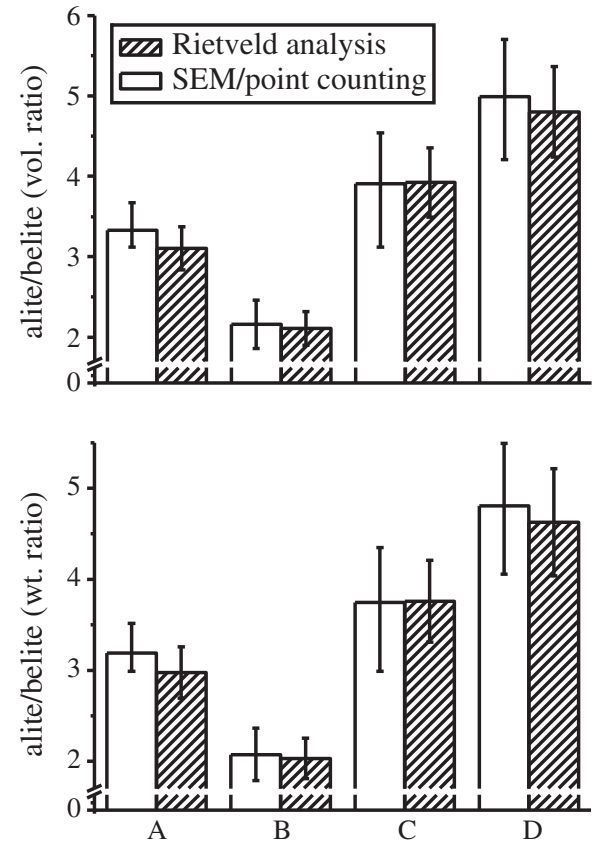

Fig. 13. Comparison of the results achieved by Rietveld and SEM/point counting.

ratio calculated by Rietveld (Eq. (4)) or, by multiplying the volumetric percent by density of the respective constituents, with the weight ratio (Eq. (5)). The densities involved in both calculations are X-ray density deduced from Rietveld analysis. Fig. 13 shows the weight and volume ratio deduced by Rietveld and SEM. The error bars for Rietveld analysis are calculated based on standard deviation in Table 2 . As with reverse Bogue calculation, we can observe a good agreement between SEM and QXRD data.

Nuclear Magnetic Resonance was used by Poulsen et al. [98] to determine the $\mathrm{Si}$ in alite to $\mathrm{Si}$ in belite atomic ratio. It can be compared with the amount of alite and belite deduced by Rietveld by using the XRF (Table 1) data and EDS analysis (Table 4) on phase compositions (Fig. 14) (see [97] for more details). We observed a good agreement between the two techniques although the quantities of alite and belite
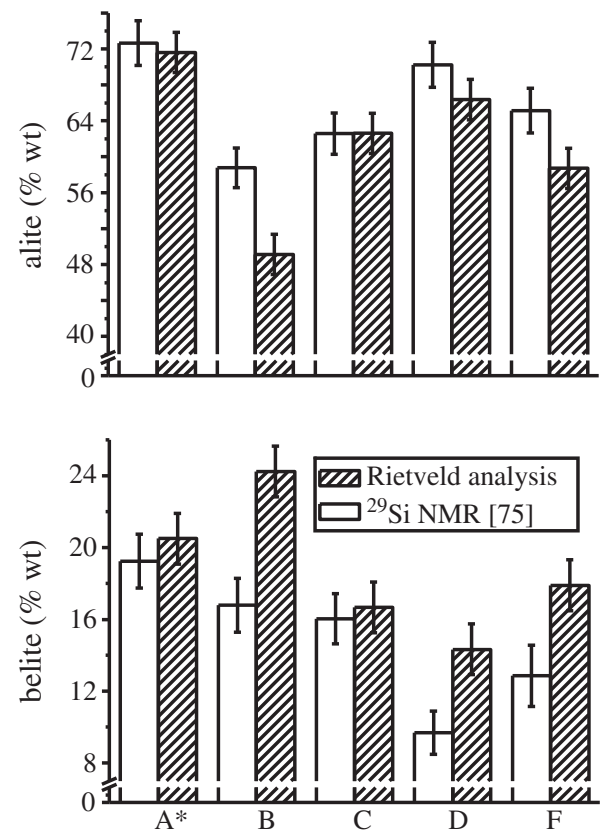

Fig. 14. Comparison of the results achieved by Rietveld and ${ }^{29} \mathrm{Si}$ NMR [98]. from NMR are generally slightly higher and lower respectively, as compared with Rietveld analysis. The main difference concerns the cement B where two polymorphs of belite are present that may induce some problem in the deconvolution of NMR spectrum.

\section{Conclusion}

As shown above, many processes may modify the intensities of the diffracted line and should be taken into account during the Rietveld refinement. The combination of selective dissolution and Rietveld analysis permit to reduce the number of parameters to refine in the last step and improve the quantification of minor phases as well as the ratio between $\mathrm{C}_{3} \mathrm{~A}$ cubic and $\mathrm{C}_{3} \mathrm{~A}$ orthorhombic. Despite the large number of parameters to refine, the Rietveld method shows an improvement of both within (repeatability) and between laboratory (reproducibility) precision as seen in last round robins.

\section{Acknowledgements}

V. Kocaba would like to acknowledge the financial support of NANOCEM. The authors acknowledge Dr Emmanuel Gallucci (EPFL, LMC) for his collaboration on SEM point counting work, Dr. Ryan Chancey from the Univ. Texas at Austin for Rietveld analysis use for comparison, and Dr Jørgen Skibsted, Univ. Aarhus in Denmark for his useful comments. The authors also acknowledge M. Enders (HOLCIM, Holderbank, Switzerland), J. Neubauer (Department of Mineralogy, Univ. Erlangen, Germany) and the two anonymous referees that considerably improve the quality of the manuscript.

\section{References}

[1] R.H. Bogue, Calculation of the compounds in Portland cement, Ind. Eng. Chem. 1 (1929) 192-197.

[2] H.F.W. Taylor, Modification of the Bogue calculation, Adv. Cem. Res. 2 (1989) 73-77.

[3] D. Sorrentino, F. Sorrentino, E. Gartner, Prediction of a Portland cement's properties from its chemical and mineralogical composition, in: F. Young, J. Skalny (Eds.), Materials Science of Concrete VII, The American Ceramic Society, 2005, pp. $1-35$

[4] H.M. Rietveld, A profile refinement method for nuclear and magnetic structures, J. Appl. Cryst. 2 (1969) 65-71.

[5] P. Stutzman, S. Leigh, Phase analysis of hydraulic cements by X-ray powder diffraction: precision, bias, and qualification, J. ASTM Int. 4 (2007) 1-11.

[6] L. León-Reina, A.G. de la Torre, J.M. Porras-Vásquez, M. Cruz, L.M. Ordonez, X Alcobé, F. Gispert-Guirado, A. Larrañaga-Varga, M. Paul, T. Fuellmann, R. Schmidt, M.A.G. Aranda, Round robin on Rietveld quantitative phase analysis of Portland cements, J. Appl. Cryst. 42 (2009) 1-11.

[7] T. Füllmann, H. Pöllmann, G. Walenta, M. Gimenez, C. Lauzon, S. HagopianBabikian, T. Dalrymple, P. Noon, Analytical methods, Int. Cem. Rev. (2001 January) 41-43.

[8] G. Walenta, T. Füllmann, M. Gimenez, Quantitative Rietveld analysis of cement and clinker, Int. Cem. Rev. (2001 June) 51-54

[9] T. Westphal, G. Walenta, T. Füllmann, M. Gimenez, E. Bermejo, K. Scrivener, H. Pöllmann, Characterisation of cementitious materials - Part III, Int. Cem. Rev. (2002 July) 47-51.

[10] H. Motzet, H. Pöllmann, U. Koenig, J. Neubauer, Phase quantification and microstructure of a clinker series with lime saturation factors in the range of 100 in: H. Justnes (Ed.), Proceedings of the $10^{\text {th }}$ International Congress on the Chemistry of cement, 1997, p. 1i039.

[11] A.G. de la Torre, M.A.G. Aranda, Rietveld mineralogical analysis of Portland cements, in: G. Grieve, G. Owens (Eds.), Proceedings of the $11^{\text {th }}$ International Congress on the Chemistry of Cement, 2003, pp. 135-145.

[12] P. Arjunan, D.M. Roy, B.E. Scheetz, P.J. Tikalsky, S. Badger, P. Arjunan, D.M. Roy, B.E Scheetz, P.J. Tikalsky, S. Badger, Quantitative phase analysis of Portland cement, in: G. Grieve, G. Owens, G. Grieve, G. Owens (Eds.), Proceedings of the $11^{\text {th }}$ International Congress on the Chemistry of Cement, 2003, pp. 115-124.

[13] J. Neubauer, H. Pöllmann, H.W. Meyer, Quantitative X-ray analysis of OPC clinke by Rietveld refinement, in: $\mathrm{H}$. Justnes (Ed.), Proceedings of the $10^{\text {th }}$ International Congress on the Chemistry of cement, 1997, p. 3v007.

[14] M. Enders, M. Berger, Quantitative XRD (Rietveld-method) in cement plants: quality control of clinker production, ZKG Int. 5 (2007) 50-59.

[15] A. Godek, D. Crutchfield, F. Blackmam, P. Storer, C. Manias, I. Madsen, Proactive not reactive, World Cement (2002) 51-55.

[16] K.W. Meyer, J. Neubauer, S. Malovrh, New quality control with standardless clinker phase determination using the Rietveld refinement, ZKG Int. 3 (1998) $152-162$ 
[17] J. Neubauer, H. Pöllmann, Rietveld calculation - A high performance instrument in automatic control systems of clinker and cement production, in: L. Jany, A. Nisperos, J. Bayles (Eds.), Proceedings of the $19^{\text {th }}$ International Conference on Cement Microscopy, 1997, pp. 295-305.

[18] J. Neubauer, Introduction of Rietveld quantitative phase analysis in OPC clinker production, in: L. Jany, A. Nisperos, J. Bayles (Eds.), Proceedings of the $20^{\text {th }}$ International Conference on Cement Microscopy, 1998, pp. 103-119.

[19] R. Schmidt, T. Feldmann, Breakthrough in phase analysis, World Cement (2003) 77-80.

[20] T. Füllmann, G. Walenta, Die quantitative Rietveld - Phaseanalyse in industrieller Anwendung, ZKG Int. 56 (2003) 1-9.

[21] I.C. Madsen, N.V.Y. Scarlett, Cement: quantitative phase analysis of Portland cement clinker, in: F.H. Chung, D.K. Smith (Eds.), Industrial Applications of X-Ray Diffraction, Marcel Dekker, 2000, pp. 415-440

[22] Q.I. Roode-Gutzmer, Y. Ballim, Phase composition and quantitative X-ray powder diffraction analysis of Portland cement and clinker, in: J. Skalny (Ed.), Materials Science of Concrete VI, The American Ceramic Society, 2001, pp. 1-48.

[23] J.C. Taylor, L.P. Aldridge, C.E. Matulis, I. Hinczak, X-ray powder diffraction analysis of cements, in: J. Bensted, P. Barnes (Eds.), Structure and Performance of Cements, Taylor and Francis, 2001, pp. 420-441.

[24] V.A. Hackley, L.-S. Lum, V. Gintaudas, C.F. Ferraris, Particle size analysis by laser diffraction spectrometry: application to cementitious powders, NIST IR 7097 (2004) 1-66.

[25] J.I. Goldstein, D. Newbury, D. Joy, C. Lyman, P. Echlin, E. Lifshin, L. Sawyer, J. Michael, Scanning Electron Microscopy and X-Ray Microanalysis, Third EditionSpringer, 2003.

[26] R.A. Young, Introduction to the Rietveld method, in: R.A. Young (Ed.), The Rietveld method, IUCr Monographs on crystallography, 5, Oxford Univ. Press, 2002, pp. $1-38$

[27] J.I. Langford, D. Louër, Powder diffraction, Rep. Prog. Phys. 59 (1996) 131-234.

[28] M. Regourd, Crystal chemistry of Portland cement phases, in: P. Barnes (Ed.), Structure and Performance of Cements, Applied Science Publishers, 1983, pp. 109-138.

[29] H.F.W. Taylor, Cement Chemistry, Academic Press, New York, 1997.

[30] H. Pöllmann, Composition of cement phases, in: J. Bensted, P. Barnes (Eds.), Structure and Performance of Cements, Taylor and Francis, 2001, pp. 25-56.

[31] F. Dunstetter, M.-N. de Noirfontaine, M. Courtial, Polymorphism of tricalcium silicate, the major compound of Portland cement clinker, 1. Structural data: review and unified analysis, Cem. Concr. Res. 36 (2006) 39-53.

[32] M.-N. de Noirfontaine, F. Dunstetter, M. Courtial, G. Gasecki, M. Signes-Frehel, Polymorphism of tricalcium silicate, the major compound of Portland cement clinker, 2. modelling alite for Rietveld analysis, an industrial challenge, Cem. Concr. Res. 36 (2006) 54-64.

[33] A.G. de La Torre, S. Bruque, J. Campo, M.A.G. Aranda, The superstructure of $C_{3} S$ from synchrotron and neutron powder diffraction and its role in quantitative analysis, Cem. Concr. Res. 32 (2002) 1347-1356.

[34] T. Tsurumi, Y. Hirano, H. Kato, T. Kamiya, M. Daimon, Crystal structure and hydration of belite, Ceram. Trans. 40 (1994) 19-25.

[35] W.G. Mumme, R.J. Hill, G. Bushnell-Wye, E.R. Segnit, Rietveld crystal structure refinements, crystal chemistry and calculated powder diffraction data for the polymorphs of dicalcium silicate and related phases, N. Jb. Miner. Abh. 169 (1995) 35-68.

[36] P. Mondal, J.W. Jeffery, The crystal structure of tricalcium aluminate, $\mathrm{Ca}_{3} \mathrm{Al}_{2} \mathrm{O}_{6}$, Acta Cryst. B 31 (1975) 689-697.

[37] F. Nishi, Y. Takeuchi, The $\mathrm{Al}_{6} \mathrm{O}_{18}$ rings of tetrahedral in the structure of $\mathrm{Ca}_{8.5} \mathrm{NaAl}_{6} \mathrm{O}_{18}$, Acta Cryst. B 31 (1975) 1169-1173.

[38] A.A. Colville, S. Geller, The crystal structure of brownmillerite, $\mathrm{Ca}_{2} \mathrm{FeAlO}_{5}$, Acta Cryst. B 27 (1971) 2311-2315.

[39] Q. Huang, O. Chmaissem, J.J. Caponi, C. Chaillout, M. Marezio, J.L. Tholence, A Santoro, Neutron powder diffraction study of the crystal structure of $\mathrm{HgBa}_{2} \mathrm{Ca}_{4}$ $\mathrm{Cu}_{5} \mathrm{O}_{12+\delta}$ at room temperature and at $10 \mathrm{~K}$, Phys. C 227 (1994) 1-9.

[40] H.E. Petch, The hydrogen positions in portlandite, $\mathrm{Ca}(\mathrm{OH})_{2}$, as indicated by the electron distribution, Acta Cryst. 14 (1961) 950-957.

[41] D. Taylor, Thermal expansion data. I. binary oxides with the sodium chloride and wurtzite structure, M O, Trans. J. Brit. Ceram. Soc. 83 (1984) 5-9.

[42] R. Wartchow, Datensammlung nach der "Learnt profile"-methode(LP) für calcit und vergleich mit der "background peak background"-methode (BPB), Zeit. Kristall. 186 (1989) 300-302.

[43] H. Effenberger, A. Kirfel, G. Will, Studies of the electron density distribution of dolomite, $\mathrm{CaMg}\left(\mathrm{CO}_{3}\right)_{2}$, Mineral. Petrol. 31 (1983) 151-164.

[44] J.D. Jorgensen, Compression mechanisms in alpha-quartz structures $-\mathrm{SiO}_{2}$ and $\mathrm{GeO}_{2}$, J. Appl. Phys. 49 (1978) 5473-5478.

[45] A.G. de la Torre, M.-G. Lopez-Olmo, C. Alvarez-Rua, S. Garcia-Granda, M.A.G. Aranda, Structure and microstructure of gypsum and its relevance to Rietveld quantitative phase analyses, Powder Diffr. 19 (2004) 240-246.

[46] H. Weiss, M.F. Bräu, How much water does calcined gypsum contain? Angew. Chem. Int. Ed. 48 (2009) 3520-3524.

[47] F.C. Hawthorne, R.B. Ferguson, Anhydrous sulfates II. Refinement of the crystal structure of anhydrite, Can. Miner. 13 (1975) 289-292.

[48] J.A. McGinnety, Redetermination of the structures of potassium sulphate and potassium chromate: the effect of electrostatic crystal forces upon observed bond lengths, Acta Cryst. B 28 (1972) 2845-2852.

[49] K. Okada, J. Ossaka, Structures of potassium sodium sulphate and tripotassium sodium disulphate, Acta Cryst. B 24 (1980) 919-921.

[50] P. Ballirano, G. Belardi, A. Maras, Refinement of the structure of synthetic syngenite $\mathrm{K}_{2} \mathrm{Ca}\left(\mathrm{SO}_{4}\right)_{2}\left(\mathrm{H}_{2} \mathrm{O}\right)$ from X-ray powder diffraction data, Neues Jb Mineral. 182 (2005) 15-21.
[51] A.M. Il'inets, Yu.A. Malinovskii, N.N. Nevskii, The crystal structure of the rhombohedral modification of tricalcium silicate, Sov. Phys. Dokl. 30 (1985) 191.

[52] F. Nishi, Y. Takeuchi, The rhombohedral structure of tricalcium silicate at 1200 degrees C, Z. Kristallogr. 168 (1984) 197-212.

[53] J.W. Jeffery, The crystal structure of tricalcium silicate, Acta Cryst. 5 (1952) 26-35

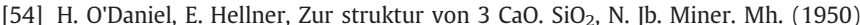
108-111.

[55] F. Nishi, Y. Takeuchi, I. Maki, Tricalcium silicate $\mathrm{Ca}_{3} \mathrm{O}\left(\mathrm{SiO}_{4}\right)$ : the monoclinic superstructure, Z. Kristallogr. 172 (1985) 297-314

[56] W.G. Mumme, Crystal structure of tricalcium silicate from a Portland cement clinker and its application to quantitative XRD analysis, N. Jb. Miner. Mh. 4 (1995) 145-160.

[57] A.G. de La Torre, R.N. De Vera, A.J.M. Cuberos, M.A.G. Aranda, Crystal structure of low magnesium-content alite: application to Rietveld quantitative phase analysis, Cem. Concr. Res. 38 (2008) 1261-1269.

[58] V.K. Peterson, B.A. Hunter, A. Ray, Tricalcium silicate $T_{1}$ and $T_{2}$ polymorphic investigations: Rietveld refinement at various temperatures using synchrotron powder diffraction, J. Am. Ceram. Soc. 87 (2004) 1625-1634.

[59] N.I. Golovastikov, R.G. Matveeva, N.V. Belov, Crystal structure of the tricalcium silicate $3 \mathrm{CaO} \mathrm{SiO}{ }_{2}=\mathrm{C}_{3} \mathrm{~S}$, Sov. Phys. Crystallogr. 20 (1975) 441-445.

[60] M. Courtial, M.-N. de Noirfontaine, F. Dunstetter, G. Gasecki, M. Signes-Frehel, Polymorphism of tricalcium silicate in Portland cement: a fast visual identification of structure and superstructure, Pow. Diffr. 18 (2003) 7-15.

[61] I. Maki, K. Goto, Factors influencing the phase constitution of alite in Portland cement clinker, Cem. Concr. Res. 12 (1982) 301-308.

[62] J. Neubauer, W. Mayerhofer, Solid solution series of ferrate and aluminate phases in OPC: Part I. The ferrate phase, Proceedings of the $22^{\text {nd }}$ International Conference on Cement Microscopy, 2000, pp. 54-64.

[63] J. Neubauer, H.-J. Kuzel, R. Sieber, Rietveld quantitative XRD analysis of Portland cement: II. Quantification of synthetic and technical Portland cement clinkers, in: L. Jany, A. Nisperos, J. Bayles (Eds.), Proceedings of the $18^{\text {th }}$ International Conference on Cement Microscopy, 1996, pp. 100-111.

[64] W.A. Gutteridge, On the dissolution of the interstitial phases in Portland cement, Cem. Concr. Res. 9 (1979) 319-324.

[65] H.F.W. Taylor, Cement Chemistry, 2nd editionThomas Teldford, 1997.

[66] R.L. Snyder, D.L. Bish, Quantitative Analysis, in: D.L. Bish, J.E. Post (Eds.), Modern Powder Diffraction, Reviews in Mineralogy, 20, Mineralogical Society of America 1989, pp. 101-144.

[67] G.W. Brindley, The effect of grain or particle size on X-ray reflections from mixed powders and alloys considered in relation to the quantitative determination of crystalline substances by X-ray methods, Phil. Mag. 36 (1945) 347-369.

[68] J.C. Taylor, C.E. Matulis, Absorption contrast effects in the quantitative XRD analysis of powders by full multiphase profile refinement, J. Appl. Cryst. 24 (1991) 14-17.

[69] I.C.Madsen, N.V.Y.Scarlett, L.M.D. Cranswick, T. Lwin, Outcomes of the international union of crystallography commission on powder diffraction round robin on quantitative phase analysis: samples $1 a$ to $1 h$, J. Appl. Cryst. 34 (2001) 409-426.

[70] A.G. de la Torre, M.A.G. Aranda, Accuracy in Rietveld quantitative phase analysis of Portland cements, J. Appl. Cryst. 36 (2003) 1169-1176.

[71] A.G. de la Torre, A. Cabeza, E.R. Losilla, M.A.G. Aranda, Quantitative phase analysis of ordinary Portland cements using synchrotron radiation powder diffraction, Z. Kristallogr. Suppl. 23 (2006) 587-592.

[72] G. Caglioti, A. Paoletti, F.P. Ricci, Choice of collimators for a crystal spectromete for neutron diffraction, Nucl. Inst. 3 (1958) 223-228.

[73] R.W. Cheary, A.A. Coelho, J.P. Cline, Fundamental parameters line profile fitting in laboratory diffractometers, J. Res. Natl. Inst. Stand. Tech. 109 (2004) 1-25.

[74] A. Zuev, Instrumental contributions to the line profile in X-ray powder diffraction. Example of the diffractometer with Bragg-Brentano geometry, in R.E. Dinnebier, S.J.L. Billinge (Eds.), Powder Difffraction, Theory and Practice, Royal Society of Chemistry, 2008, pp. 166-205.

[75] J.P. Cline, D. Balck, D. Gil, A. Henins, D. Windover, The application of the fundamental parameters approach as implemented in TOPAS to divergent beam powder diffraction data, Mat. Sci. Forum 651 (2010) 201-219.

[76] T. Füllmann, personal communication.

[77] P. Scardi, Diffraction line profile analysis of nanocrystalline powders and deformed materials, in: A. Guagliardi, N. Masciocchi (Eds.), Diffraction at the Nanoscale, Nanocrystals, Defective and Amorphous Materials, Insubria University Press, 2010, pp. 165-175.

[78] L.W. Finger, D.E. Cox, A.P. Jephcoat, A correction for powder diffraction peak asymmetry due to axial divergence, J. Appl. Cryst. 27 (1994) 892-900.

[79] O. Pritula, L. Smrcok, B. Baumgartner, On reproducibility of Rietveld analysis of reference Portland cement clinkers, Powder Diffr. 18 (2003) 16-22.

[80] D.L. Bish, R.C. Reynolds Jr., Sample preparation for X-ray diffraction, in: D.L. Bish, J.E. Post (Eds.), Modern Powder Diffraction, Reviews in Mineralogy, 20 Mineralogical Society of America, 1989, pp. 73-99.

[81] R. Jenkins, T.G. Fawcett, D.K. Smith, J.W. Visser, M.C. Morris, L.K. Frevel, JCPDS international centre for diffraction data sample preparation methods in X-Ray Powder Diffraction, Powder Diffr. 1 (1986) 51-63.

[82] H.P. Klug, L.E. Alexander, X-Ray Diffraction Procedures for Polycrystalline and Amorphous Materials, 2nd editionWiley, 1974.

[83] L.D. Mitchell, P.S. Whitfield, J.J. Beaudoin, The effects of particle statistics on quantitative Rietveld analysis of cement, in: J.J. Beaudoin, J.M. Makar, L. Raki (Eds.), Proceedings of the $12^{\text {th }}$ International Congress on the Chemistry of Cement, 2007.

[84] M. Enders, Quantitative phase analysis, World Cem. (2007) 45-49.

185] W.A. Gutteridge, Quantitative X-ray powder diffraction in the study of some cementive materials, Brit. Ceram. Proc. 35 (1984) 11-23. 
[86] M. Enders, Sample preparation for quantitative X-ray diffraction in cement plants: sources of errors and solutions, ZKG Int. 58 (2005) 28-37.

[87] S. Seufert, C. Hesse, F. Goetz-Neunhoffer, J. Neubauer, Quantitative determination of anhydrite III from dehydrated gypsum by XRD, Cem. Concr. Res. 39 (2009) 936-941.

[88] R. Jenkins, R.L. Snyder, Introduction to X-ray powder diffractometry, in: J.D. Winefordner (Ed.), Chemical Analysis a series of monographs on chemistry and its applications, Wiley, 1996, p. 231.

[89] W.A. Dollase, Correction of intensities for preferred orientation in powder diffractometry: application of the March model, J. Appl. Cryst. 19 (1986) 267-272.

[90] N.C. Popa, Microstructural properties: texture and macrostress effects, in: R.E. Dinnebier, S.J.L. Billinge (Eds.), Powder Difffraction, Royal Society of Chemistry, Theory and Practice, 2008, pp. 332-375.

[91] H. Sitepu, B.H. O'Connor, D. Li, Comparative evaluation of the March and generalized spherical harmonic preferred orientation models using X-ray diffraction data for molybdite and calcite powders, J. Appl. Cryst. 38 (2005) 158-167.

[92] T. Moederl, Improved backloading for better results, Mat. Sci. For. 378-381 (2001) 240-245.

[93] P.E. Stutzman, Guide for X-ray powder diffraction analysis of Portland cement and clinker, NIST Intern. Rep. 5755 (1996) 1-38.
[94] F. Goetz-Neunhoeffer, J. Neubauer, Crystal structure refinement of Na-substituted $\mathrm{C}_{3} \mathrm{~A}$ by Rietveld analysis and quantification in OPC, in: H. Justnes (Ed.), Proceedings of the $10^{\text {th }}$ International Congress on the Chemistry of cement, 1997, p. 1 i056.

[95] B. Lothenbach, G. Le Saout, E. Gallucci, K. Scrivener, Influence of limestone on the hydration of Portland cements, Cem. Concr. Res. 38 (2008) 848-860.

[96] J. Neubauer, Application of Rietveld quantitative X-ray diffraction analysis on technically produced OPC clinkers, OPC's and OPC/HAC blends, in: F.A. FingerInstitute for Building Materials Science, Bauhaus-University Weimar (Ed.), Proceedings of the 17th Internationale Baustofftagung (IBAUSIL), 1 (1997) 127-136.

[97] L.P. Aldridge, Accuracy and precision of an X-ray diffraction method for analyzing Portland cements, Cem. Concr. Res. 12 (1982) 437-446.

[98] S.L. Poulsen, V. Kocaba, G. Le Saoût, H.J. Jakobsen, K.L. Scrivener, J. Skibsted, Improved quantification of alite and belite in anhydrous Portland cements by ${ }^{29}$ Si MAS NMR: effects of paramagnetic ions, Solid State NMR 36 (2009) 32-44.

[99] L.P. Aldridge, Effects of analytical errors on the Bogue calculation of compound composition, Cem. Tech. 4 (1973) 177-183.

[100] D.H. Campbell, J.S. Galehouse, Quantitative clinker microscopy with the light microscope, Cem. Concr. Aggr. 13 (1991) 94-96. 